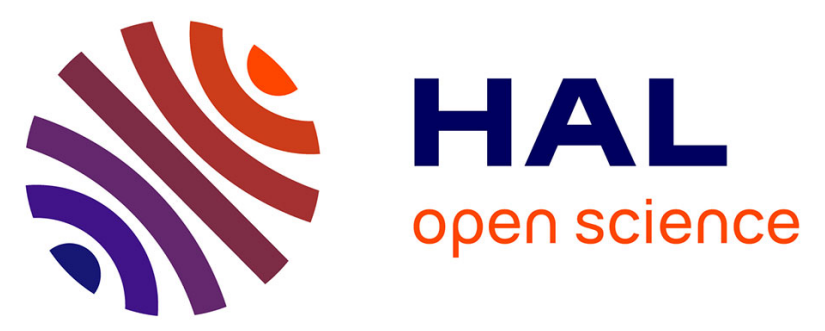

\title{
High frequency floral changes at the Paleocene-Eocene boundary revealed by comparative biomarker and palynological studies
}

\author{
Sylvain Garel, Florence Quesnel, Jérémy Jacob, Emile Roche, Claude Le \\ Milbeau, Christian Dupuis, Mohammed Boussafir, François Baudin, Johann \\ Schnyder
}

\section{To cite this version:}

Sylvain Garel, Florence Quesnel, Jérémy Jacob, Emile Roche, Claude Le Milbeau, et al.. High frequency floral changes at the Paleocene-Eocene boundary revealed by comparative biomarker and palynological studies. Organic Geochemistry, 2014, 77, pp.43-58. 10.1016/j.orggeochem.2014.09.005 . insu-01092576

\section{HAL Id: insu-01092576 \\ https://hal-insu.archives-ouvertes.fr/insu-01092576}

Submitted on 9 Dec 2014

HAL is a multi-disciplinary open access archive for the deposit and dissemination of scientific research documents, whether they are published or not. The documents may come from teaching and research institutions in France or abroad, or from public or private research centers.
L'archive ouverte pluridisciplinaire HAL, est destinée au dépôt et à la diffusion de documents scientifiques de niveau recherche, publiés ou non, émanant des établissements d'enseignement et de recherche français ou étrangers, des laboratoires publics ou privés. 


\section{High frequency floral changes at the Paleocene-Eocene Boundary revealed by comparative biomarker and palynological studies}

$\underline{\text { Sylvain Garel }}^{\text {a, b, c, d, e,f }} *$, Florence Quesnel ${ }^{\text {c, d, e, f }}$, Jérémy Jacob ${ }^{\text {c, d, e }}$, Emile Roche ${ }^{\mathrm{g}}$, Claude

Le Milbeau $^{\text {c, d, e }}$, Christian Dupuis ${ }^{\text {h }}$, Mohammed Boussafir ${ }^{\text {c, d, e }}$, François Baudin ${ }^{\text {a, b }}$ and Johann Schnyder ${ }^{\text {a, b }}$

${ }^{\text {a }}$ Sorbonne Universités, UPMC Univ Paris 06, UMR 7193, ISTeP, F-75005, Paris, France

${ }^{\mathrm{b}}$ CNRS, UMR 7193, ISTeP, F-75005 Paris, France

${ }^{\mathrm{c}}$ Université d'Orléans, ISTO, UMR 7327, 45071 Orléans, France

${ }^{\mathrm{d}}$ CNRS/INSU, ISTO, UMR 7327, 45071 Orléans, France

${ }^{\mathrm{e}}$ BRGM, ISTO, UMR 7327, BP 36009, 45060 Orléans, France

${ }^{\mathrm{f}}$ BRGM GéoRessources/GAT, 45060 Orléans Cedex 2, France

${ }^{\mathrm{g}}$ Paléontologie végétale, ULg, Sart Tilman, 4000 Liège, Belgium

${ }^{\mathrm{h}}$ Laboratoire de Géologie Fondamentale et Appliquée, Faculté Polytechnique de Mons, Université de Mons, rue de Houdain 9, B-7000 Mons, Belgium

\footnotetext{
* Corresponding author at: Université Pierre et Marie Curie- Paris 6, Institut des Sciences de la Terre de Paris, CNRS UMR 7193, case courrier 117, Tour 56-66 $5^{\text {ème }}$ étage, 4 place Jussieu, 75005 Paris, France. E-mail address: sylvain.garel@upmc.fr; (S. Garel).
} 


\section{ABSTRACT}

The Cap d'Ailly area (Upper Normandy, France) shows several terrestrial-lagoonal sections recording the negative Carbon Isotope Excursion (CIE) associated with the Paleocene-Eocene Thermal Maximum (PETM; 55.8 Ma). A study of the biomarkers and spores/pollen content of the Vasterival section gave complementary information on paleofloral changes that occurred around the PaleoceneEocene (P-E) boundary. Aliphatic hydrocarbon fractions revealed a high abundance of vascular plant biomarkers, including tricyclic diterpanes derived from conifers, fernenes derived from ferns and desA-triterpenes derived from angiosperms. Whereas the vegetation of the depositional environment surroundings seemed alternately dominated by ferns and angiosperms (as revealed by biomarkers), the regional flora seemed strictly dominated by angiosperms such as Juglandaceae (as revealed by pollen). Spores/pollen assemblages reveal no major turnover in the paleovegetation, but slight variation in vegetation composition. However, both biomarkers and spores/pollen exhibited two intervals of rapid floral changes: the first occurred around the P-E boundary and the second at the top of the strictly terrestrial unit that coincides with a marine transgression. Comparison of these data with published paleoclimatic results, obtained from the same samples, indicated that the first interval of floral change was correlated with strong paleohydrological perturbations, whereas the second was linked to an increasing marine influence.

Keywords: PETM, molecular geochemistry, pollen and spores study, floral changes, paleohydrology, Dieppe-Hampshire Basin 


\section{Introduction}

The Paleocene-Eocene (P-E) boundary, 55.8 Ma (Charles et al., 2011), is characterized by an event of extreme $\left(4-8^{\circ} \mathrm{C}\right)$ and short lived (160-210 ka) warming (Kennett and Stott, 1991; Zachos et al., 2003; Sluijs et al., 2006; Aubry et al., 2007; Westerhold et al., 2008; Murphy et al., 2010; Storme et al., 2012a). The Paleocene-Eocene Thermal Maximum (PETM) is defined by a global negative Carbon Isotope Excursion (CIE) of 2.5-6 \% (Kennett and Stott, 1991; Koch et al., 1992; Magioncalda et al., 2004; Zachos et al., 2005), which may have been triggered by the rapid and massive injection of isotopically light carbon, such as methane clathrates, into the ocean-atmosphere system (Dickens et al., 1995; Higgins and Schrag, 2006).

The PETM had major consequences for the marine realm, where it is associated with a rise in surface and bottom ocean temperatures (Kennett and Stott, 1991; Zachos et al., 2001), acidification of the deep ocean (Zachos et al., 2005), a large benthic foraminifera extinction (Kennett and Stott, 1991; Kaiho et al., 1996) and an increase in abundance and geographical range of dinoflagellates Apectodinium spp. (Bujak and Brinkhuis, 1998; Crouch et al., 2003; Aubry et al., 2007). On land, the PETM is associated with the appearance and rapid dispersal of modern mammalian orders (Gingerich, 1989, 2006; Smith et al., 2006) and changes in the hydrological cycle (Pagani et al., 2006; Schmitz and Pujalte, 2007; Handley et al., 2011; 2012; Tipple et al., 2011; Garel et al., 2013).

Palynological studies have not found any global crisis among floral communities at the P-E boundary (Harrington and Kemp, 2001; Wing et al., 2003, 2005; Collinson et al., 2009). However, local and regional changes have been detected, such as a decrease in the abundance of gymnosperms during the PETM, observed in the Arctic (Schouten et al., 2007) and in landmasses bordering the North Sea Basin (Kender et al., 2012), as well as in Wyoming (Wing et al., 2005; Smith et al., 2007). In the London Basin, the vegetation adapted to episodic fires, which characterizes the latest Paleocene, disappears after the P-E boundary (Collinson et al., 2003, 2007 2009). At lower latitudes, a decrease in diversity has been observed in the paratropical flora of America (US Gulf Coast) during the earliest Eocene (Harrington and Jaramillo, 2007), whereas the equatorial flora of eastern Colombia and western Venezuela was subjected to an increase in diversity (Jaramillo et al., 2010). 
Comparative studies of biomarker and spores/pollen content may provide complementary information for investigating paleofloral changes. Indeed, whereas the biomarker content of sediments most likely reflects vegetation within and immediately around the depositional environment (Ficken et al., 2002; Schwark et al., 2002; Regnery et al., 2013), palynological assemblages generally provide a more regional signal, since pollen and spores are often transported to the depositional environment over a longer distance than biomarkers (Andrieu et al., 1997; Jansen et al., 2013).

Only a few PETM studies have used the relative abundance of biomarkers to reconstruct the evolution of terrestrial plants (Schouten et al., 2007; Handley et al., 2008, 2011, 2012; Carvajal-Ortiz et al., 2009). Among these, only Schouten et al. (2007) proposed a comparison between palynological and biomarker data.

In northwestern Europe, the P-E boundary is represented by terrestrial and lagoonal deposits rich in organic matter $(\mathrm{OM})$ from the Paris Basin "Sparnacian" and coeval stratigraphic units from adjacent basins (Thiry and Dupuis, 1998; Collinson et al., 2003; Steurbaut et al., 2003; Aubry et al., 2005). The eastern part of the Dieppe-Hampshire Basin shows several sections with Sparnacian facies known for their swamp deposits containing well preserved OM (Magioncalda et al., 2001; Smith et al., 2011; Storme et al., 2012b; Garel et al., 2013). The only molecular study performed on the "Sparnacian" of the Dieppe-Hampshire Basin (Garel et al., 2013), and the low resolution of the former palynological studies of the basin did not make it possible to obtain precise information on floral changes during the PETM (Gruas-Cavagnetto, 1966; Dupuis and Gruas-Cavagnetto, 1985; Roche et al., 2009).

Here we present a high resolution palynological and molecular record of the Vasterival section, where the CIE onset has been identified (Storme et al., 2012b; Garel et al., 2013). Comparison of palynological and biomarker data should provide insight into the evolution of the composition and diversity of the floral communities at the P-E boundary in the Vasterival area. This multi-proxy approach should also decipher how the floral communities of a mid-latitude-swamp responded to the climatic and environmental changes that occurred at the P-E boundary. 


\section{Vasterival section}

This section is included in the Cap d'Ailly area, known for its Sparnacian outcrops (Bignot, 1965; Dupuis and Steurbaut, 1987; Dupuis et al., 1998; Magioncalda et al., 2001; Aubry et al., 2005) on the Côte d'Albâtre of Upper Normandy (Fig. 1). The $2 \mathrm{~m}$ thick section reveals $1.5 \mathrm{~m}$ of terrestrial deposits overlain by $50 \mathrm{~cm}$ of lagoonal sediments of the "Sables et Argiles à Ostracodes et Mollusques" Member (SAOM Mb - Soissonnais Formation; Aubry et al., 2005; Fig. 2). The terrestrial deposits include a lignite complex (L1, Mortemer Formation) of the reference section of the Cap d'Ailly area (Dupuis et al., 1998; Storme et al., 2012b; Garel et al., 2013) and a thin bed of clay with root traces (Fig. 2). The deposits are composed of three clay beds with evidence of fossil roots (Rb1 to Rb3; Fig. 2), five lignite beds (Lb1 to Lb5; Fig. 2), two clay beds exhibiting carbonate nodules (Nb1 and Nb2; Fig. 2) and three clay beds presenting no root evidence or nodules (Cb1 to $\mathrm{Cb} 3$; Fig. 2). Fossil shells of a freshwater bivalve, Unio spp. can be observed between $60 \mathrm{~cm}$ and $1 \mathrm{~m}$ above the base of the section. The overlying lagoonal deposits are composed of an alternation of sands, silts and clays rich in mollusc shells. Only the lower part of the SAOM Mb can be observed in the section.

For the section, the $\mathrm{P}-\mathrm{E}$ boundary has been unraveled from chemostratigraphy based on bulk $\mathrm{OM} \delta^{13} \mathrm{C}$ values (Storme et al., 2012b) and the PETM interval refined by the CIE recorded in the $\delta^{13} \mathrm{C}$ values of vascular plant-derived $n$-alkanes (Garel et al., 2013). These results locate the P-E boundary in the Lb3 bed, $98 \mathrm{~cm}$ above the base of the Vasterival section (Fig. 2), and indicate that the PETM extends to the top of the section, as the CIE recovery is missing from Vasterival (Garel et al., 2013). Furthermore, two environmental changes have been identified in the section (Garel et al., 2013). The first is concomitant with the beginning of the CIE. The second occurs in the last terrestrial beds (i.e. Rb3 and Lb5) and appears related to an increasing marine influence. Lastly, studies of OM $\delta^{15} \mathrm{~N}$ values and compound-specific $\delta \mathrm{D}$ values have shown that the latest Paleocene in Vasterival was characterized by strong hydrological perturbations, switching from wet to dry conditions, and that the PETM was marked by a wetter climate with stronger seasonality (Storme et al., 2012b; Garel et al., 2013). 


\section{Methods}

\subsection{Field work and sample collection}

The outcrop was cleaned by removing the superficial layers $(5-10 \mathrm{~cm})$ before sampling. A series of blocks (10 cm high x $5 \mathrm{~cm}$ thick) were collected in order to obtain continuous sampling of the section. Each sample was wrapped in Al foil and stored in low bleed Whirl-pak bags immediately after collection. In order to minimize contamination, the outer rim $(0.5-1 \mathrm{~cm})$ of every sample was removed before analysis.

\subsection{Molecular geochemistry}

\subsubsection{Lipid extraction and separation}

Dried powdered samples (28) were extracted using an accelerated solvent extraction (ASE 200, Dionex@), with a dichloromethane (DCM): $\mathrm{MeOH}(9: 1 \mathrm{v} / \mathrm{v})$. After evaporation of the solvents with a stream of $\mathrm{N}_{2}$, each total lipid extract was separated with solid phase extraction using aminopropylbonded silica into a neutral fraction (elution with DCM:isopropanol 2:1 v/v), and an acid and a polar fraction not discussed here. The neutral fraction was then fractionated using flash chromatography with a Pasteur pipette filled with silica (activated at $120{ }^{\circ} \mathrm{C}$ for $24 \mathrm{~h}$ and deactivated with 5 wt. $\%$ water). The aliphatic hydrocarbon fraction was collected via elution with heptane.

\subsubsection{Gas chromatography-mass spectrometry (GC-MS)}

Identification and quantification of compounds in the aliphatic hydrocarbon fraction was performed using a Thermo-Finnigan TRACE-PolarisGCQ gas chromatograph (GC-MS system). The gas chromatograph was fitted with an Rtx-5 MS column (30 m x $0.25 \mathrm{~mm}$ i.d., $0.25 \mu \mathrm{m}$ film thickness) with $5 \mathrm{~m}$ of guard column: an aliquot $(2 \mu \mathrm{l})$ of the fraction diluted in toluene was injected in splitless mode, with the injector temperature at $280{ }^{\circ} \mathrm{C}$ and the chromatograph oven at $40{ }^{\circ} \mathrm{C}$. After $1 \mathrm{~min}$, the oven temperature was increased to $120^{\circ} \mathrm{C}$ at $30{ }^{\circ} \mathrm{C} / \mathrm{min}$, then to $300{ }^{\circ} \mathrm{C}$ (held $30 \mathrm{~min}$ ) at $5{ }^{\circ} \mathrm{C} / \mathrm{min}$. The carrier gas was Helium at a constant $1 \mathrm{ml} / \mathrm{min}$. 
The MS instrument was operated in the electron ionization mode at $70 \mathrm{eV}$ and the scanned from $\mathrm{m} / \mathrm{z}$ 50 to 600 .

The concentration of each biomarker was estimated by measuring peak areas on specific ion chromatograms. After applying a correction factor calculated as the ratio between the peak area on the total ion current (TIC) chromatogram and the peak area on the specific ion chromatogram, the TIC peak area of each biomarker was compared with that of the internal standard ( $5 \alpha$-cholestane), divided by the wt. of sample extracted. Compounds were tentatively assigned from comparison of relative retention times and mass spectra with published data.

\subsection{Pollen and spores}

Palynological preparation was performed on the 28 samples (20 of which were also used for biomarker analysis): one from each of $\mathrm{Rb} 1, \mathrm{Lb} 1, \mathrm{Nb} 1, \mathrm{Lb} 2, \mathrm{Cb} 2$ and $\mathrm{Lb} 4$, three from each of $\mathrm{Cb} 1$, $\mathrm{Lb} 3, \mathrm{Rb} 2, \mathrm{Rb} 3, \mathrm{Lb} 5$ and $\mathrm{SAOM} \mathrm{Mb}$ and four from $\mathrm{Cb} 3$. Two palynological slides per sample were prepared at the British Geological Survey and Liège University laboratories according to standard preparation procedures (Erdtman, 1960; Roche et al., 2008): dissolution of carbonate and silicate with $\mathrm{HCl}$ and $\mathrm{HF}$ acid digestion, sieving between 106 and $10 \mu \mathrm{m}$, neutralization with distilled water and centrifugation, then mounting the remaining residue on the slides. A slight acetolysis was performed for the samples richer in OM.

All the pollen and spores were counted within each slide at Liège University. The pollen and spore morphological and taxonomic nomenclature follows Pflug (1952, 1953), Krutzsch (1957), Roche (1973) and Krutzsch and Vanhoorne (1977).

Palynological material was stored at BRGM (Orléans, France) and the University of Liège (Belgium).

\section{Results}

4.1. Molecular geochemistry 
The aliphatic hydrocarbon fractions were dominated by long chain $n$-alkanes with odd/even predominance (Fig. 3), indicative of a major contribution from terrestrial vascular plants (Eglinton et al., 1962; Eglinton and Hamilton, 1967). They also showed a significant concentration of $\mathrm{C}_{29}-\mathrm{C}_{31}$ hopanes and hop-17(21)-ene (Fig. 3). As Garel et al. (2013) had already interpreted the Vasterival $n$ alkane data, we focus here on more specific biomarkers (Table 1).

\subsubsection{Biomarker identification}

Five hydrocarbons (DT1-DT5 Fig. 3; Table 1) with $\mathrm{C}_{20}$ tricyclic diterpane structures were detected between the $n-\mathrm{C}_{19}$ and $n-\mathrm{C}_{21}$ alkanes. The most abundant tricyclic diterpanes were pimarane and sandaracopimarane, assigned according to Hagemann and Hollerbach (1980), Philp (1985) and Otto et al., (1997). The other three diterpanes could not be assigned.

Five compounds (DA1 to DA5), eluting between $n-\mathrm{C}_{23}$ and $n$ - $\mathrm{C}_{25}$ alkanes, were assigned as des-Atriterpenes (Fig. 3; Table 1). The mass spectra of DA1, DA2 and DA3 displayed $\mathrm{M}^{+}$at $m / z, 328$, consistent with des-A-triterpene structures, whereas DA4 displayed $\mathrm{M}^{+}$at $m / z 330$ indicative of a desA-triterpane. Abundant fragments at $m / z$ 189, 203, 204 and 218 in the spectra of DA1, DA2 and DA3 were indicative of a C-ring cleavage typical of oleanene and ursene structures, followed by retroDiels-Alder rearrangement (Djerassi et al., 1962). Based on mass spectral resemblance with published data (Corbet et al., 1980; Logan and Eglinton, 1994; Jacob et al., 2007) and on the relative retention times of ursene and oleanene-type $\Delta^{12}$ and $\Delta^{13,18}$ isomers, we tentatively assigned compound DA1 as des-A-olean-13(18)-ene, DA2 as Des-A-olean-12-ene and DA3 as des-A-urs-12-ene. DA4 was assigned as des-A-lupane from comparison with published mass spectra (Corbet et al., 1980; Philp, 1985).

The spectrum of DA5 (Fig. 3), which eluted later than DA1, DA2 and DA3, also displayed a $\mathrm{M}^{+}$at $\mathrm{m} / \mathrm{z}$ 328 associated with intense fragments at $m / z, 231,243$ and 313. From the spectral resemblance to reported compounds (Kimble 1972; Loureiro and Cardoso, 1990), we tentatively assigned the compound as a des-A-fernene. 
In addition to hopanes, 4 pentacyclic triterpenes were present. Compound Fer (Fig. 3; Table 1) eluted between $n-\mathrm{C}_{31}$ and $n$ - $\mathrm{C}_{32}$ alkanes. The spectrum had $\mathrm{M}^{+}$at $m / z 410$ associated with intense fragments at $m / z 243,255$ and 257. This pattern is indicative of a fernene structure, either $\Delta^{7}, \Delta^{8}$ or $\Delta^{9(11)}$ since these isomers cannot be distinguished on the basis of their spectra (Shiojima et al., 1992). Compound Ono (Fig. 3; Table 1) eluted between $n$ - $\mathrm{C}_{30}$ and $n-\mathrm{C}_{31}$, with a base peak at $m / z, 123, \mathrm{M}^{+}$at $m / z 414$ and another intense fragment at $\mathrm{m} / \mathrm{z} 191$ that exceeded $\mathrm{m} / \mathrm{z}$ 193. According to published spectra, this compound was assigned as onocerane I (Henderson et al., 1969; Pearson and Obaje, 1999; Jacob et al., 2004). Compound Hop (Fig. 3; Table 1) eluted between $n-\mathrm{C}_{31}$ and $n-\mathrm{C}_{32}$. The mass spectrum showed $\mathrm{M}^{+}$at $m / z$ 414, with intense fragments at $m / z$ 161, 367 and 231. According to published spectra (Shiojima et al., 1992), it was assigned as hop-17(21)-ene. Compound Neo (Fig. 3; Table 1) eluted at $39.6 \mathrm{~min}$ and its spectrum displayed $\mathbf{M}^{+}$at $\mathrm{m} / \mathrm{z} 410$ together with significant fragments at $\mathrm{m} / \mathrm{z} 191,218$ and 203. According to published spectra (Shiojima et al., 1992), it was assigned as neohop-13(18)-ene.

\subsubsection{Biomarker quantification}

In order to report the evolution of biomarker abundance independently of the origin of the OM in sediments, the concentration of each specific biomarker was expressed relative to the $n-\mathrm{C}_{31}$ alkane concentration (hence with no unit). Since $n-\mathrm{C}_{31}$ is produced by all vascular plants, this relative abundance should reflect the evolution of different vascular plant contributions to the sediments. Samples 27 and 44 (Fig. 2) had a very low content of vascular plant biomarkers. Garel et al. (2013) showed that the $\mathrm{OM}$ of $\mathrm{Rb} 1$ and $\mathrm{Nb} 1$ beds has suffered from severe degradation, making interpretation of the biomarker data from these two samples unreliable.

The relative concentrations of diterpanes ([DT1 + DT2 + DT3 + DT4 + DT5] $/ n-\mathrm{C}_{31}$; Fig. 4b). It from 0 to 0.72 and displayed two remarkable intervals. The first one showed an increasing trend with two positive peaks (values of 0.31 and 0.28 ): one slightly before the CIE onset, at the bottom of the $\mathrm{Cb} 3$ bed; and the second during the CIE onset at the top of the same lignite bed. The second one displayed increasing values, from $120 \mathrm{~cm}$ to the bottom of the $\mathrm{Rb} 3$ bed, where a strong increase led to the highest relative proportion before decreasing through the Lb5 bed. 
The most abundant des-A-triterpenes were des-A-olea-13(18)-ene and des-A-lupane (DA1 and DA4;

Fig. 4c; Table 1) with values ranging respectively from 0 to 0.46 and from 0 to 0.31 . DA1 relative concentration is characterized by two peaks in $\mathrm{Rb} 3$ and Lb5 with relatively low values below and above it. On the other hand, DA4 concentration showed relatively high values at $106 \mathrm{~cm}$ in $\mathrm{Cb} 3$, from 130 to $143 \mathrm{~cm}$ and at $175 \mathrm{~cm}$ in the SAOM Mb.

Des-A-olean-12-ene and des-A-urs-12-ene (DA2 and DA3; Fig. 4d; Table 1) showed relatively similar trends throughout the section. The relative concentrations ranged from 0 to 0.03 for DA2 and from 0 to 0.09 for DA3. After a peak in concentration in sample 51, both curves exhibited a decreasing trend, finishing at sample 112 within the CIE. Upward, DA2 and DA3 increased, reaching a maximum in Lb5. In the SAOM Mb the concentration of both biomarkers was low and stable.

Des-A-fernene (DA5; Fig. 4d) and $\mathrm{C}_{30}$ fernene (Fer; Fig. 4e) showed similar trends. Concentrations values ranged from 0 to 0.17 for DA5 and from 0 to 1.42 for Fer. Both biomarkers showed concentration peaks at 90 and $98 \mathrm{~cm}$ and a strong increase within Lb5, where they reached their maximum concentration at $147 \mathrm{~cm}$. The top of $\mathrm{Lb} 5$ and the SAOM Mb were marked by a strong decrease in the concentration of both compounds.

Hop-17(21)-ene (Hop; Fig. 4f), one of the most abundant biomarkers, ranged from 0 to 5.5. The curve reached the pre-CIE maximum at $85 \mathrm{~cm}$ (4.26), followed by a decreasing trend between 98 and 120 $\mathrm{cm}$. From the base of Rb3 to the top of Lb5, Hop concentrations showed a very strong increase, reaching the highest values before a strong decrease in the SAOM Mb.

Onocerane I relative concentration (Ono; Fig. 4g) ranged from 0.01 to 2.5. A decreasing trend ending at the top of $\mathrm{Cb} 1$ preceded an interval between 74 and $90 \mathrm{~cm}$ marked by a strong increasing trend that led to the highest concentration. A progressive decrease characterized the interval between 90 and 112 $\mathrm{cm}$. In $\mathrm{Rb} 2$, the concentration showed a strong increase, leading to the highest relative Eocene concentration (2.26). This peak preceded a drop, ending at the top of Lb5.

Relative concentration of neohop-13(18)-ene (Neo; Fig. 4h) ranged from 0 to 2.04 and showed a trend similar to the one of Hop: a pre-CIE maximum at $85 \mathrm{~cm}$ (1.97) followed by a decreasing trend 
between 98 and $120 \mathrm{~cm}$, and a strong rise from the base of $\mathrm{Rb} 3$ to the Lb5 where it reached the highest value in the section.

\subsection{Pollen and spores assemblages and evolution}

\subsubsection{Palynomorph richness and content}

A mean of 140 individual pollen grains and spores were counted per slide, but pollen and spore richness was highly variable (Fig. 5b). Among the 28 samples, two were barren of palynomorphs (27 and $147 \mathrm{~cm})$, six others were poor, containing $<100$ pollen grains and spores $(85,95,115,120,130$ and $140 \mathrm{~cm}$ ), indicated by small white squares on the curves; the remaining samples were more or less rich (from 304 to 111 pollen and spores counted).

Marine palynomorphs (dinoflagellate cysts, acritarchs and other miscellaneous algae) were studied in six samples: 136 and $138 \mathrm{~cm}$ were very poor in marine palynomorphs, $149 \mathrm{~cm}$ was poor; 155,175 and $196 \mathrm{~cm}$ were rich.

The number of pollen and spore taxa in samples was 28 in average, but highly variable: from a minimum of 10 to a maximum of 40 (Fig. 5c). Apart from one notable exception $(115 \mathrm{~cm})$, the spores/pollen diversity followed the total number of individual grains counted (Fig. $5 \mathrm{~b}$ and c). Four intervals of palynological richness and diversity could be delineated along the succession:

- from the bottom to $85 \mathrm{~cm}$ an initial interval with a decreasing trend,

- a second (from 85 to $112 \mathrm{~cm}$ ) and a third interval (from 115 to $143 \mathrm{~cm}$ ) with increasing trends, separated by a pronounced threshold between 112 and $115 \mathrm{~cm}$,

- after a gap between 143 and $149 \mathrm{~cm}$, a fourth interval with stable values and a significant diversity until the top of the section.

Considering only samples containing $>100$ pollen and spores counted as providing statistically relevant information, and excluding other samples from the calculations (cf. small white squares in Fig. 5 c), then the total number of pollen and spore taxa was 32 on average, and the evolution was rather different showing much more stable values with a minimum of 22 and a maximum of 40 . This 
approach was also adopted for the following statistical abundance calculations and resulting palynological curves: the small white squares are only shown but are excluded from the curves and the corresponding samples containing $<100$ pollen and spores counted are excluded from the calculations (Fig. 5d-f).

\subsubsection{Pollen and spore content}

\subsubsection{Spores/pollen distribution among angiosperms, gymnosperms and ferns}

The spores/pollen assemblage (Fig. 5 and Supplementary information) was dominated by angiosperm pollen (68.1 to $95 \%$; mean, $83 \%)$ and was rather homogeneous along the succession, although the relative abundance of fern spores and gymnosperm pollen varied from a few percent to almost $30 \%$. Bryophyte spores were absent; the abundance of gymnosperm pollen grains varied from 0 (4 samples) to $10 \%$ (mean, $3.8 \%$ ); fern spores were more abundant and varied from 2.3 ( 1 sample) to $23.5 \%$ (mean, 13\%). Considering the low contribution from gymnosperm pollen grains, angiosperm and fern relative abundances were mathematically anti-correlated.

The relative abundance of fern taxa showed a succession of increases and decreases but with a lesser amplitude than for angiosperms, from $2.3 \%$ to $23.5 \%$. Whilst the overall trend was a decrease, the more detailed evolution from the bottom to the top delineated a zigzagging trend. The most frequent changes occurred in Lb3, Cb3 and Lb4, showing 4 successive sharp peaks with maxima at $98 \mathrm{~cm}$ and $109 \mathrm{~cm}$ and minima at $103 \mathrm{~cm}$ and $112 \mathrm{~cm}$ (. Other maxima occurred in $\mathrm{Cb} 1$ and $\mathrm{Rb} 3$ and minima in $\mathrm{Nb} 1, \mathrm{Lb} 2$ to the base of $\mathrm{Lb} 3$ and in $\mathrm{Lb} 5$, from where fern taxa showed stable low relative abundances until the top of the SAOM Mb.

The relative abundance of gymnosperm taxa also showed a zigzag evolution all along the succession from $0 \%$ to a maximum of $9.9 \%$, with a decrease and then a stable trend as overall trend, The most frequent variations occurred also in $\mathrm{Lb} 3, \mathrm{Cb} 3$ and $\mathrm{Lb} 4$, showing 5 successive peaks with maxima at 98 $\mathrm{cm}, 103 \mathrm{~cm}$ and $109 \mathrm{~cm}$ and minima at $101 \mathrm{~cm}$ and $112 \mathrm{~cm}$. The relative abundance of gymnosperm taxa showed a mean negative trend in that interval, as for ferns but in contrast to 
angiosperms. Other maxima occurred in $\mathrm{Nb} 1$ to the base of $\mathrm{Cb} 1$ and $\mathrm{Rb} 3$, and minima in $\mathrm{Lb} 5$. From the base of the SAOM Mb values increased again sharply and remained stable until the top around 5\%. The relative abundance of angiosperm taxa showed a succession of sharp increases and decreases delineating again a zigzag evolution all along the succession from $68 \%$ to a maximum slightly above 95\%. Although the overall trend was an increase, 2 pronounced increases were delineated in $\mathrm{Cb} 1$ and from $\mathrm{Rb} 3$ to $\mathrm{Lb} 5$, and the most frequent variations occurred also in $\mathrm{Lb} 3, \mathrm{Cb} 3$ and $\mathrm{Lb} 4$, showing 4 successive sharp peaks with minima at $98 \mathrm{~cm}$ and $109 \mathrm{~cm}$ and maxima at $103 \mathrm{~cm}$ and $112 \mathrm{~cm}$ interrupted a mean increasing trend. A regular decrease was observed from Lb4to Rb3 and, in the SAOM Mb values were variable but with a much lower amplitude than previously.

\subsubsection{Facies distribution of fern spores and gymnosperm/angiosperm pollen}

Fern spore maxima were not associated with particular facies (Fig. 5), as they occurred in clay (lower half of $\mathrm{Cb} 1$ and upper part of $\mathrm{Cb} 3$ ), lignite (Lb3) or clay with fossil root (Rb3) beds. Fern spores were much less abundant in the SAOM Mb.

Angiosperm pollen maxima seemed to be more dependent on facies type, as they occurred mainly in all the lignite beds but the lowest and in only one clay bed (Cb3). However, angiosperm pollen abundance curves also showed minima in lignite and clay beds, so this relationship with facies types was not so clearly evident. Their abundance was more significant and constant in the SAOM Mb (85.4-94.7\%). Gymnosperm pollen maxima seemed to be associated with some nodules, rooted and clay beds, and never in lignite beds.

\subsubsection{More specific pollen and spore occurrences}

The majority of spore and pollen taxa in Vasterival (Supplementary information) are commonly found in the Sparnacian facies of the Dieppe-Hampshire and Paris Basins and in the Tienen Fm of Belgium (Chateauneuf and Gruas-Cavagnetto, 1968; Gruas-Cavagnetto, 1966, 1968; Roche, 1973; Krutzsch 
and Vanhoorne, 1977; Dupuis and Gruas-Cavagnetto, 1985; Cavagnetto, 2000; Roche et al., 2009 and unpublished data).

Among the fern taxa, Schizeaceae (Lygodium spp.) and Polypodiaceae were the most abundant, followed by Diksoniaceae, Schizeaceae (Ruffordia and/or Mohria spp.) and Cyatheaceae (?).

Gymnosperm taxa belonged mainly to Taxodiaceae and Pinaceae, while angiosperm taxa were dominated by Juglandaceae (Platycarya and Engelhardtia: up to 35\%), Sparganiaceae (up to 30\%), and possible pre-Myricaceae (Plicapollis pseudoexcelsus: up to 14\%) and, in a few samples, by Gentianaceae/Euphorbiaceae (Pistillipollenites macgregorii Rouse 1962: up to 28\%). Other Juglandaceae (Subtriporates), Tiliaceae and Myricaceae were present and occasionally reached 5\% to even $10 \%$ of the spores/pollen assemblage. Tricolporate and tricolpate grains were not rare and reached respectively $10 \%$ and 6\%, among which were Castaneaceae and pre Quercus. Other Juglandaceae (Carya) were present and more abundant upwards in the SAOM Mb (up to 9\%). Palm pollen grains (Monocolpates) were present all along the succession and also increased upwards to reach almost $12 \%$ of the spores/pollen assemblage in the SAOM Mb, while neither Dicolpate nor Spinizonocolpate (Nypa) grains were found. Normapolles species other than P. pseudoexcelsus were present but not numerous or diverse, even below the P/E boundary. Restionaceae (Milfordia hungarica W. Kr. et Vanh. 1970) were often present but never abundant (up to 5\%). Triporopollenites robustus Th. et Pf. 1953 (Corylaceae?) was always present (up to 4.5\%) while Sapotaceae (Tetracolporate) and Icaninaceae (Compositoipollenites) were present but occasional and rare (1\% and $0.5 \%$ respectively). Trivestibulopollenites paleobetuloides Roche 1973 (Betulaceae?) was present in only one sample of the SAOM Mb and rare (0.7\%), while Polyvestibulopollenites verus Th. et Pf. 1953 (Betulaceae, Alnus) was absent.

\section{Discussion}

\subsection{Origin of biomarkers}


Diterpenoids are known to be produced especially by gymnosperms and to be the main constituent of conifer resin (Streibl and Herout, 1969; Noble et al., 1985). Even if some diterpenoids allow familylevel distinction, most do not allow species-level distinction of conifers (Otto and Wilde, 2001; Stefanova et al., 2005).

Fernenes are commonly found in ferns (Ageta et al., 1968; Ourisson et al., 1979; Paull et al., 1998). Several authors indicate that bacteria and Gramineae also produce compounds with a fernane structure (Ohmoto et al., 1970; Brassell and Eglinton, 1983; Volkman et al., 1986; Hauke et al., 1992). As no Gramineae pollen were found in Vasterival (Supplementary information), we can exclude a Gramineae origin for the fernenes in Vasterival. Furthermore, comparison of the relative concentrations of Fer with the relative concentrations of hopanes (Fig. 6a) showed no clear correlation. Because precursors of hopanes occur mainly in bacteria (Ourisson et al., 1979; Rohmer et al., 1980; Kannenberg and Poralla, 1999), the distinct behavior of hopanes and $C_{30}$ fernene in our samples suggests that it has a fern origin here. Comparison of the relative concentration of des-A-fernene with that of hopanes (Fig. 6b) showed no correlation, also suggesting a distinct origin for these compounds. We therefore consider des-A-fernene as a tracer for ferns.

Hop-17(21)-ene (Hop) and neohop-13(18)-ene (Neo) are unsaturated and re-arranged hopane derivatives, respectively (Ageta et al., 1987; Shiojima et al., 1992). At first sight, this would suggest a bacterial origin. However, comparison of the relative concentrations of these biomarkers with the relative concentrations of hopanes showed no clear correlation $\left(R^{2}<0.2\right.$ for both biomarkers $)$, suggesting another origin for these compounds. Furthermore, Hop and Neo exhibited a clear correlation $\left(R^{2} 0.73\right)$, suggesting a common source, and have both been isolated from fern species (Ageta et al., 1968; Shiojima and Ageta, 1990). As they display a correlation with the $\mathrm{C}_{30}$ fernene (Fig.6c and d) and since they have not been found in other organisms, it is likely that, in Vasterival, these biomarkers also have a fern origin.

Onocerane I (Ono) has a 8,14-seco-gammacerane structure, possible precursors of which have been reported in ferns and angiosperms (Pearson and Obaje, 1999; Jacob et al., 2004). However comparison of Ono relative concentration with that of the $\mathrm{C}_{30}$ fernene (Fig. 6e) showed no correlation. As ferns 
were excluded as a source for Ono, we consider an angiosperm species as the most probable source of this compound in Vasterival.

Pentacyclic triterpenes with a lupane, oleanane or ursane structure, as well as their diagenetic derivatives, such as des-A-triterpanes, found in soils and sediments are classically used as tracers of angiosperms (Cranwell, 1984; Logan and Eglinton, 1994; Peters et al., 2005; Jacob et al., 2007). When functional groups are preserved, pentacyclic triterpenes allow a more precise distinction of their source organisms: at the family, genus or even species level (Jacob et al., 2005; Zocatelli et al., 2010; Lavrieux et al., 2011; Le Milbeau et al., 2013). This is not the case in Vasterival because the more polar fractions did not provide any oxygenated compounds. Pentacyclic triterpenes with a lupane, oleanane or ursane structure and their derivatives could thus be attributed solely to angiosperms. From these considerations, we use in the following discussion tricyclic diterpanes as tracers of gymnosperms; $\mathrm{C}_{30}$ fernene, des-A-fernene, neohop-13(18)-ene and hop-17(21)-ene as tracers of ferns; and the other des-A-triterpanes (except des-A-fernene) and onocerane I as tracers of angiosperms.

\subsection{Evolution of group-specific biomarkers}

In order to discuss the evolution of each group, we considered the proportions of specific tracers of gymnosperms, ferns and angiosperms relative to the sum of vascular plant biomarkers with the following equations:

Fern biomarkers (Fig. 7b): (DA5+Fer+Hop+Neo) x 100/

(DT1+DT2+DT3+DT4+DT5+DA1+DA2+DA3+DA4+DA5+Fer+Hop+Neo+Ono)

Gymnosperm biomarkers (Fig. 7d): (DT1+DT2+DT3+DT4+DT5) x 100/

(DT1+DT2+DT3+DT4+DT5+DA1+DA2+DA3+DA4+DA5+Fer+Hop+Neo+Ono)

Angiosperm biomarkers (Fig. 7f): (DA1+DA2+DA3+DA4+Ono) x 100/

(DT1+DT2+DT3+DT4+DT5+DA1+DA2+DA3+DA4+DA5+Fer+Hop+Neo+Ono)

The denomination of each biomarker refers to Table 1. 
Fern biomarker proportions range from $13.3 \%$ to $94 \%$ (avg. of $46.8 \%$ ). Except for 2 peaks in samples 51 and 85 (77\% and $87 \%$ respectively), the values are relatively stable before the CIE (avg. of $48 \%$ ). The beginning of the CIE coincides with high frequency variation in the relative proportions of fern biomarkers (average of 52.5\%), where they successively reach their minimum and maximum (at samples 109 and 112 respectively). The $\mathrm{Rb} 2$ bed is initially marked by a drop in fern biomarker relative proportions, followed by a stable trend from sample 120 to sample 136 . This trend is followed by a strong increase within the Rb3 bed, leading to very high values in the Lb5 bed (avg. of 86\%). Finally, whereas the base of the SAOM Mb exhibits a low fern biomarker proportion (avg. of 18\%), the top of the section shows high values.

Gymnosperm biomarkers are the least abundant among the vascular plant specific biomarkers, with a relative proportion ranging from $0 \%$ to $9.7 \%$ (avg. 3\%). From the base of the section to $85 \mathrm{~cm}$, values are relatively stable (avg. 2.3\%). Upwards, gymnosperm biomarker relative proportion reaches the pre-CIE level within the Lb3 bed (avg. 5\%). The beginning of the CIE shows a decreasing trend ending in sample 112, where no diterpanes were found. The Rb2 bed initially exhibits a peak in gymnosperm biomarker relative proportion that is followed by stable values up to sample 136 (avg. $2.8 \%$ ). A sudden increase in the relative proportion occurs at the top of the Rb3 bed and leads to the maximum for the section at the base of the Lb5 bed. Upwards, this peak is followed by a drop in relative proportion that leads to very low values in the SAOM Mb.

Angiosperm biomarkers are the most abundant vascular plant specific biomarkers in Vasterival, with a relative proportion ranging from $5.6 \%$ to $86 \%$ (average of 50.1\%). At the base of the section, angiosperm biomarker proportion successively shows a drop from $80 \%$ to $20 \%$, a strong increase up to $60 \%$ and relatively stable values throughout the $\mathrm{Cb} 1$ and $\mathrm{Lb} 2$ beds. An interval of high frequency variation, with relative proportions ranging from $5.6 \%$ to $86 \%$, extends from $\mathrm{Cb} 2$ to $\mathrm{Lb} 4$ (avg. of 46.3\%). From samples 120 to 136, angiosperm biomarker relative proportion is high and stable (avg. of 72\%). Upwards, a strong drop beginning in Rb3 leads to very low values in Lb5 (avg. of 9\%). In the SAOM Mb, angiosperm biomarker proportion shows high values at the base and a drop at the top. 


\subsection{Environmental and climatic reconstruction from pollen and spore assemblages}

The whole pollen and spore assemblage (Supplementary information) of Vasterival indicates a subtropical climate, as often reported for the Sparnacian flora of the Paris, Dieppe-Hampshire, London, Belgian and German (sub)basins (Fritel, 1910; Krutzsch, 1957; Chateauneuf and GruasCavagnetto, 1968; Gruas-Cavagnetto, 1968; 1978; Dupuis and Gruas-Cavagnetto, 1985; Roche, 1973; Krutzsch and Vanhoorne, 1977; Cavagnetto, 2000; Collinson et al., 2003, 2009; Roche et al., 2009; Riegel et al., 2012). Spores/pollen data depict vegetation adapted to humid conditions (Sparganiaceae, ferns, Myricaceae, Taxodiaceae). This is consistent with the succession of depositional environments reconstructed by other indicators such as palynofacies and biogeochemical proxies (Garel et al., 2013). Furthermore, spores/pollen input from the hinterland often occurred, as shown by the significant proportions and peaks of Juglandaceae pollen (Gruas-Cavagnetto, 1968; Roche, 1973), particularly from sample 70 and upwards (Table and Fig. in Supplementary information). Those could result from enhanced fluvial discharge (floods) in the swampy environment, in accord with a high proportion of freshwater Pediastrum algae mentioned in similar parts of the Vasterival section and interpreted as a consequence of strong seasonal nutrients and detrital input (Garel et al., 2013).

High values of Pistillipollenites macgregorii Rouse 1962 were noted in some beds (e.g. samples 109$112,25 \%$ and $28 \%$ respectively) and remain significant (from $5 \%$ to $15 \%$ ) below and particularly above the P/E boundary (Table and Fig in Supplementary information). This taxon is often present, and in a few instances very abundant, in the Sparnacian facies of the Paris and adjacent basins (GruasCavagnetto, 1968; Roche, 1973; Krutzsch and Vanhoorne, 1977; Cavagnetto, 2000; Roche et al., 2009 and unpublished data) and in the Schöningen Fm (Early Eocene) of Northern Germany (Riegel et al., 2012). Moreover, a very high proportion (10-52\%) of this taxon has been sporadically reported in all lithologies of both the Late Paleocene and the PETM interval of the Cobham section (Collinson et al., 2009). Although first tentatively ascribed to Leguminosae or Flacourtiaceae (Gruas-Cavagnetto, 1968; Roche, 1973), in situ P. macgregorii pollen was later found in some Paleogene flowers. Gentianaceae or Euphorbiaceae have been suggested as the potential source plants (Crepet and Daghlian, 1981; Stockey and Manchester, 1988). Yet, this kind of gemmate pollen may have been produced by several 
angiosperm families via convergence during evolution (Stockey and Manchester, 1988; Cavagnetto, 2000). This taxon is therefore present in Vasterival, Cobham and Schöningen well described P/E lignitic successions and subtropical swamp environments, which were more or less (i) close to the seashore, (ii) subjected to fire regimes in the surrounding landscapes, (iii) subjected to hinterland detrital influx, i.e. wetlands with seasonal events. Nevertheless, given the available information, it is too speculative to propose a more detailed paleoenvironmental/paleoclimatic interpretation for this taxon.

The spores/pollen content evolves in the SAOM Mb: while $P$. macgregorii disappears, Platycarya and Engellhardtia, ferns and Sparganiaceae abundances decrease. Furthermore, the diversity and richness of palm pollens increase, which is also consistent with the lagoonal environment reconstructed from sedimentological and palynological investigations (Dupuis and Steurbaut, 1987; Dupuis et al., 1998; Aubry et al., 2005; Roche et al., 2009 and unpublished data; Storme et al., 2012b; Garel et al., 2013).

\subsection{Comparison between pollen/spores and biomarker records}

Both pollen/spores and biomarker records indicate a low contribution of gymnosperms $(<5 \%$ on average) at the P-E boundary (Fig. 7). However, whereas spores/pollen assemblage suggests a strict dominance of angiosperms ( $83 \%$ on average), the dominance of angiosperms as evidenced by biomarkers is less obvious ( $51 \%$ on average), with 11 samples displaying < $50 \%$ angiosperm biomarkers. Furthermore, whereas fern biomarkers represent up to $87 \%$ (47\% on average) of vascular plant biomarkers, fern spores never constitute $>25 \%$ (13\% on average) of the spores/pollen assemblage. Therefore, it seems that fern spores and biomarkers are globally less abundant than angiosperm pollen and biomarkers in the Vasterival section, and that detailed comparison shows a more complicated relationships between the two markers.

Two major peaks in fern biomarkers occur before the CIE (samples 51 and 85). The first peak is also evidenced in more elevated spores/pollen, whereas the second peak corresponds to a sample poor in palynomorphs (Fig. 7). Above the P-E boundary, 5 samples display high fern biomarkers 
concentration (samples 98, 106, 112, from 143 to 149 and 196), 2 being correlated with peaks of fern spores (98 and 196). Regarding the peak in fern biomarkers within Lb5, it occurs just above a peak in fern spore concentration (sample 136 to sample 143; Fig. 7). Thus, although there is no strict correlation of these fern biomarkers and spore peaks, both tracers indicate a strong contribution of ferns below the SAOM Mb.

Gymnosperm biomarker relative proportion shows four peaks (samples 90, 95, 106 and from 138 to 143). The first, second and third peaks are not correlated with peaks in gymnosperm pollen (Fig. 7). The last one is partly correlated with a peak in gymnosperm pollen (sample 138), but reaches the highest value at $143 \mathrm{~cm}$, a sample poor in palynomorphs.

The lowest relative concentration of angiosperm biomarkers below the P-E boundary is observed at the base of $\mathrm{Cb} 1$, in agreement with spores/pollen data, and within $\mathrm{Cb} 2$ (Fig. 7). Within $\mathrm{Cb} 3$, the angiosperm biomarker curve exhibits a zigzag shape with strong amplitudes (up to 80\%) that is not observed in the spore/pollen record. In Rb2, the values are relatively high (around 70\%) and stable. $\mathrm{Rb} 3$ exhibits a strong decrease in angiosperm biomarkers that is also observed, with lower amplitude, in the spores/pollen record (Fig. 7). Angiosperm biomarker concentration in Lb5 is very low (around $10 \%$ ) and stable, unlike angiosperm pollen that is all $>75 \%$ in this bed. Except for sample 196, the relative concentration of angiosperm biomarkers and pollen in the SAOM Mb is high (avg. $81.5 \%$ and $91 \%$ respectively).

Thus, the relative proportions of spores/pollen and biomarkers show no strict correlation in the Vasterival section (Fig. 7). While we cannot exclude the possibility that the discrepancy could be due to an incomplete inventory of biomarkers, it may be explained by the different spatial representativeness of each tracer. The spores/pollen abundance in sediments is affected by processes such as transportation (i.e. aqueous or eolian), sorting during transport and the catchment capacity of the depositional environment (Traverse, 1988; Faegri and Iversen, 1989; Andrieu et al., 1997).

Therefore, it does not inevitably represent the composition of the vegetation in the surroundings. On the other hand, biomarker records generally represent the vegetation within the immediate surroundings of the depositional environment (Bechtel et al., 2002; Ficken et al., 2002; Schwark et al., 
2002). This difference in spatial representativeness could also explain why fern biomarkers dominate in some samples, whereas fern spores never represent $>23.5 \%$ of the spores/pollen assemblages. This difference may indicate that a large amount of ferns grew around the depositional environment, whereas the region was dominated by angiosperms, as indicated by spores/pollen record.

Furthermore, it seems that beds $\mathrm{Rb} 3$ and Lb5 show a stratigraphic lag between peaks in spores/pollen and peaks in biomarkers, the latter always occurring after the former (Fig. 7). Recently, a high resolution study found a similar lag (estimated at $2 \mathrm{ka}$ ) in Holocene sediments (Jansen et al., 2013), which was also thought to result from differences in representativeness between the two tracers in some environments (Jansen et al., 2013). Therefore, in Rb3 and Lb5, pollen/spores could have recorded regional vegetation changes before their occurrence in the Vasterival area revealed by biomarkers, thus showing the spatial nature of these progressive changes.

\subsection{Changes in vegetation composition}

\subsubsection{Intervals of high frequency-floral changes}

Although biomarker and spores/pollen records are not strictly correlated, they exhibit two intervals of high frequency change (I1 and I2), in comparison with the rest of the section (Fig. 7).

I1 is located around the P-E boundary, between 85 and $112 \mathrm{~cm}$ (Fig. 7). It exhibits high frequency and high magnitude biomarker changes (several tens of \%). These changes are also evidenced in spores/pollen results that show similar frequencies, the magnitudes of the variation being much smaller (around 10\%), and the first peak occurring later $(98 \mathrm{~cm})$. In I1, the biomarker record exhibits the following succession of concentration peaks (Fig. 8b): ferns $(85 \mathrm{~cm})$, gymnosperms $(90 \mathrm{~cm})$, angiosperms $(91 \mathrm{~cm})$, gymnosperms $(95 \mathrm{~cm})$, ferns $(98 \mathrm{~cm})$, angiosperms $(103 \mathrm{~cm})$, ferns and gymnosperms $(106 \mathrm{~cm})$, angiosperms $(109 \mathrm{~cm})$ and ferns $(112 \mathrm{~cm})$. On the other hand, spores/pollen data show the following succession of peaks (Fig. 8c): ferns $(98 \mathrm{~cm})$, gymnosperms and angiosperms $(103 \mathrm{~cm})$, ferns (109) and angiosperms $(112 \mathrm{~cm})$.

I 2 is in the last terrestrial deposits, between 138 and $155 \mathrm{~cm}$ (Fig. 7). I2 starts with a drop in both angiosperm pollen and biomarkers (Fig. 8). This drop is followed by a peak in gymnosperm 
biomarkers $(143 \mathrm{~cm})$ and then by a peak in fern biomarkers $(147 \mathrm{~cm})$. The peak in fern spores and gymnosperm pollen is concomitant at $138 \mathrm{~cm}$.

Spores/pollen and biomarker changes recorded in I1 and I2 are not related to lithological changes (Fig.

7): in I1, variation in the relative concentration of both tracers occurs mainly within Lb3 and Cb3, whereas it occurs within Rb3 and Lb5 in I2. Thus, although depositional environment variation can result in changes in the pollen/spore catchment capacity and/or preservation of biomarkers (Faegri and Iversen, 1989; Sinninghe Damsté et al., 2002; Killops and Killops, 2005), this cannot explain the changes observed in Vasterival. Therefore, despite the non-immediate and strict correlation between the two indicators, pollen/spores assemblage and biomarkers, both indicate that strong vegetation changes occurred within I1 and I2.

\subsubsection{Impact on plant diversity}

Most of the taxa (75\%) identified from palynology are present before and after the P-E boundary. The sum of the 14 species present only after the P-E boundary never represents $>3 \%$ of the spores/pollen assemblage in I1 or $>5 \%$ in I2 (Supplementary. information). Among these, five taxa may be considered as good regional stratigraphic markers for the Early Eocene and are generally absent from the Upper Paleocene units of the Dieppe-Hampshire and Paris Basin: Thomsonipollis magnificus W. Kr. 1960, Triatriopollenites plicatus Th. et Pf. 1953, Tricolporopollenites oleoides Roche et Schuler, 1976 n. comb. 2008, Tricolporopollenites iliacus Th. et Pf. 1953 and Caryapollenites circulus W. Kr. 1961 (Roche et al., 2009 and unpublished data).

Furthermore, only one taxon disappears after the P-E boundary in Vasterival: Anacolosidites efflatus Erdt. 1954/pseudoefflatus W. R. 1959 (Supplementary information). Surprisingly this taxon has seldom been observed in the area and only after the P/E boundary (Roche et al., 2009 and unpublished data). Its occurrence below the P/E boundary at Vasterival is an unexpected finding and could result from particular local conditions. 
Therefore, the vegetation changes in I1 and I 2 are not characterized by vegetation appearing or disappearing, but by varying proportions of species that were present before and that persist after the P-E boundary.

These data show that, in the context of a swamp developed in a mid-latitude warm climate, the response of vegetation to a major climatic change was discreet.

In northwestern Europe, the lack of $\delta^{13} \mathrm{C}$ data accompanying former palynological work conducted in the Paris, Belgian and Dieppe-Hampshire Basins (Chateauneuf and Gruas-Cavagnetto, 1968; GruasCavagnetto, 1968; Roche, 1973; Krutzsch and Vanhoorne, 1977; Cavagnetto, 2000) precludes any direct comparison with our results. However, a study of similar deposits from Cobham in the London Basin also indicates that no major change affected the vegetation around the P-E boundary (Collinson et al., 2009). The same conclusions arose from a palynological study in the Belgian Basin (Kallo borehole; Steurbaut et al., 2003).

Nevertheless contrasting results obtained at higher latitudes in the North Sea Basin indicate more drastic vegetation change: spore and pollen assemblage from the 22/10a-4 core records a rapid and major shift in vegetation at the CIE onset. The pollen of swamp conifers (Inaperturopollenites hiatus) and pine communities in the uppermost Paleocene deposits are largely replaced in the unit recording the beginning of the PETM via pollen and spores from more general taxa, including fern and various angiosperms among which Juglandaceae are dominant (Kender et al., 2012). Comparable results have been obtained from Jutland (Denmark) from the Østerrenden drill core (Willumsen et al., 2013), with slightly different angiosperm taxa in the deposits in which the CIE was detected. Both results show major and differentiated changes in vegetation in landmass surrounding the North Sea Basin, although they have only $10^{\circ}$ of latitudinal difference with Vasterival, Cobham and Kallo.

At much lower latitude, the paratropical palynoflora of the US Gulf Coast shows a pronounced decrease in diversity during the Early Eocene (Harrington and Jaramillo, 2007). In the equatorial palynoflora of eastern Colombia and western Venezuela, the PETM is characterized by an increase in rainforest vegetation compared with the Late Paleocene (Jaramillo et al., 2010). 
As in Europe, the mid-latitude-vegetation response to the PETM warming was subtle in North America, as there were no major pollen and spore species extinctions or appearances (Harrington and Kemp, 2001; Harrington et al., 2005), but only vegetation composition changes including a northward intra-continental migration, as seen from macroflora studies (Wing et al., 2005). Although similar high resolution data from Asia are not available, it thus seems that mid-latitude-flora of the northern hemisphere did not undergo major changes but only variations in vegetation composition across the $\mathrm{P} / \mathrm{E}$ boundary.

\subsection{Causes of paleofloral changes}

In order to decipher whether or not these paleofloral changes are related to the PETM climatic variations, we compared them with available/published paleoclimatic results. Fig. 8 shows the evolution of the $\mathrm{C}_{27} n$-alkane ( $n$ - $\mathrm{C}_{27}$ ) hydrogen isotopic composition $(\delta \mathrm{D})$ and the evolution of the relative proportion of $n-\mathrm{C}_{27}$ (i.e. $n-\mathrm{C}_{27} / n-\mathrm{C}_{27}+n-\mathrm{C}_{29}+n-\mathrm{C}_{31}$ ) compared with changes in plant groups in Vasterival.

The $\delta \mathrm{D}$ values of vascular plant-derived leaf wax $n$-alkanes is affected by (i) the $\delta \mathrm{D}$ values of meteoric water, which is affected by the source of precipitation, and the temperature and amount of precipitation (Sauer et al., 2001; Chikaraishi and Naraoka, 2003; Sachse et al., 2004); (ii) the extent of leaf water transpiration and soil water evaporation, depending on humidity and temperature (Smith and Freeman, 2006; Feakins and Sessions, 2010); and (iii) interspecific variability (Smith and Freeman, 2006; Chikaraishi and Naraoka, 2007). In Vasterival, Garel et al. (2013) showed that the $n$ alkane $\delta \mathrm{D}$ variation is controlled mainly by hydrological changes.

Comparison of the distribution of long chain $n$-alkanes with pollen distributions has shown that low proportions of $n-\mathrm{C}_{27}$ are linked to (i) vegetation growing under harsh environmental (e.g. mesohaline waters) and (ii) arid or boreal climatic conditions. Conversely, high proportions of $n$ - $\mathrm{C}_{27}$ may indicate climatic conditions favorable for the development of vegetation such as equatorial or temperate climates (Schwark et al., 2002; Rommerskirchen et al., 2003). 
In Vasterival, the Upper Paleocene part of I1 is marked by high amplitude variation in $n-\mathrm{C}_{27} \delta \mathrm{D}$ values (Fig. 8) indicative of climatic perturbation. According to Garel et al. (2013), these paleohydrological changes relate to a latest Paleocene climatic event that is also recorded in England, where the emergence of a flora adapted to episodic fire is observed below the CIE (Collinson et al., 2007), and in Wyoming (Secord et al., 2010). This global event could be a consequence of a strong episode of volcanic activity, which could have indirectly triggered off the PETM (Secord et al., 2010; Garel et al., 2013). In Vasterival, it is thus likely that the vegetation changes observed for the Late Paleocene were driven by this climatic event.

The beginning of the PETM in Vasterival is marked by a drop in $n-\mathrm{C}_{27} \delta \mathrm{D}$ values and a strong increase in $n-\mathrm{C}_{27}$ relative proportion (Fig. 8), both indicating moister conditions (Rommerskirchen et al., 2003; Feakins and Sessions, 2010). However, since the resolution for the $\delta \mathrm{D}$ data is lower than for the spores/pollen and biomarker data, it cannot explain the high frequency changes in vegetation in I1 above the P-E boundary (Fig. 8). The $n-\mathrm{C}_{27}$ relative proportion exhibits a peak at $106 \mathrm{~cm}$ followed by a strong decrease at $109 \mathrm{~cm}$ that could also be indicative of moister conditions. Thus, it seems that the vegetation changes in I1 are primarily driven by the paleoclimatic perturbations affecting the latest Paleocene and the beginning of the PETM. I1 is between two intervals of relatively stable hydrologic conditions and limited floral change. Vegetation developed during I1 may therefore represent a transition flora between those two episodes of climatic and environmental relative stability.

The second interval of vegetation changes I 2 is marked by stable $n-\mathrm{C}_{27} \delta \mathrm{D}$ values and a drop in $n-\mathrm{C}_{27}$ relative proportion (Fig. 8), the interpretation of which could be contradictory. However, palynofacies observations revealed the presence of marine dinoflagellates in the $\mathrm{Rb} 3$ and $\mathrm{Lb} 5$ beds, indicative of an increasing marine influence (Garel et al., 2013). This probably caused an increase in salinity in the swamp environment, leading to a greater stress for plant communities. As vegetation growing under harsh environmental conditions synthetizes longer $n$-alkanes (Schwark et al., 2002), this salinity increase may explain the drop in $n$ - $\mathrm{C}_{27}$ relative proportions in I2. Thus, the stable and low $n-\mathrm{C}_{27} \delta \mathrm{D}$ values associated with the presence of dinoflagellates in this interval (Garel et al., 2013) suggest that 
the vegetation changes observed in I 2 are not primarily caused by climatic change, but probably by increasing salinity in the coastal marsh environment, resulting from a rise in sea level.

\section{Conclusions}

Comparison of vascular plant biomarkers and spores/pollen data from the Vasterival section provides information on the paleofloral changes that occurred around the Paleocene-Eocene boundary in the Dieppe-Hampshire Basin. Here, biomarkers are considered to be representative of the vegetation immediately around the depositional environment, which seems alternately dominated by ferns and angiosperms, and pollen and spores that represent a more regional flora, essentially dominated by angiosperms. This difference in representativeness could result in a stratigraphic lag between peaks in spores/pollen and peaks in biomarkers in the top of the Vasterival section, pollen and spores recording regional vegetation changes before their occurrence in the depositional environment area.

Additionally, like many other mid-latitude sites, Vasterival spores/pollen assemblages dos not point to vegetation appearing or disappearing, but only slight variation in vegetation composition. This contrasts with the significant floral changes observed in records from lower and higher latitudes.

Moreover, both tracers reveal two intervals of high-frequency changes in vegetation composition. The first begins immediately below the CIE onset, and finishes just above the P/E boundary. The second occurs at the top of the terrestrial sediments and coincides with a marine incursion. Comparison of these results with published paleoclimatic data obtained from the same section and samples indicates that the first interval coincides with an interval of high frequency paleohydrological changes linked to the PETM. It also shows that the second interval is the consequence of the swamp environment progressive drowning, caused by a marine transgression.

This comparative approach has proved useful for past vegetation reconstruction around the $\mathrm{P} / \mathrm{E}$ boundary in a mid-latitude area close to the paleo North Sea shore. However, it could be improved if the comparative representativeness of biomarker and spores/pollen concentrations were better understood. Finally, our approach to this singular hyperthermal event should be extended to other 
terrestrial environments (e.g. proximal and distal alluvial basins, lakes) and to sites under distinct paleolatitudes or paleoelevations in order to better constrain the spatial heterogeneity of climate impacts on terrestrial ecosystems.

\section{Acknowledgements}

S. Garel thanks the Ministère de l'Enseignement Supérieur et de la Recherche for a doctoral grant.

The paper is a contribution to the Research cooperation contract financially supported by the BRGM ("Paléosurface éocène-PETM" research project), and to the BRGM Scientific Program "Genèse et caractéristiques des Régolithes".

The work is a part of the PalHydroMil project, supported by Agence Nationale de la Recherche Grant ANR-2010-JCJC-607-01.

We thank J. Flint (British Geological Survey), M. Giraldo (Liège University) and F. Savignac (Paris 6 University) for their technical support.

Special thanks go to C. Truffert (Research Division of the BRGM) for encouraging and supporting research on stratigraphy and paleoclimatic changes of the Early Paleogene in NW Europe. We also thank E. Rowley-Jolivet for English revision and J.S. Watson and an anonymous reviewer for comments.

Finally, we thank Prof. J. Maxwell for his constructive comments and corrections. 


\section{References}

Ageta, H., Shiojima, K., Arai, Y., 1968. Fern constituents: neohopene, hopene-II, neohopadiene, and fernadiene isolated from Adiantum species. Chemical Communications, 1105-1107.

Ageta, H., Shiojima, K., Arai, Y., 1987. Acid-induced rearrangement of triterpenoid hydrocarbons belonging to the hopane and migrated hopane series. Chemical and Pharmaceutical Bulletin $35,2705-2716$.

Andrieu, V., de Beaulieu, J.-L., Ponel, P., Reille, M., 1997. Les distorsions de l'enregistrement pollinique de l'histoire de la végétation du dernier cycle climatique: exemples de séquences lacustres du Sud de la France. Geobios 21, 195-202.

Aubry, M.-P., Ouda, K., Dupuis, C., Berggren, W.A., Van Couvering, J.A., Ali, J., Brinkhuis, H., Gingerich, P.R., Heilmann-Clausen, C., Hooker, J., Kent, D.V., King, C., Knox, R.W.O.B., Laga, P., Molina, E., Schmitz, B., Steurbaut, E., Ward, D.R., 2007. The Global Standard Stratotype-section and Point (GSSP) for the base of the Eocene Series in the Dababiya section (Egypt). Episodes 30, 271-286.

Aubry, M.-P., Thiry, M., Dupuis, C., Berggren, W.A., 2005. The Sparnacian deposits of the Paris Basin: A lithostratigraphic classification. Stratigraphy 2, 65-100.

Bechtel, A., Sachsenhofer, R.F., Kolcon, I., Gratzer, R., Otto, A., Püttmann, W., 2002. Organic geochemistry of the Lower Miocene Oberdorf lignite (Styrian Basin, Austria): its relation to petrography, palynology and the palaeoenvironment. International Journal of Coal Geology $51,31-57$.

Bignot, G., 1965. Le gisement éocène du Cap d'Ailly (près de Dieppe Seine-Maritime). Bulletin de la Société Géologique de France série 7, 273-283.

Brassell, S.C., Eglinton, G., 1983. Steroids and triterpenoids in deep sea sediments as environmental and diagenetic indicators. In: Bjorøy, M. et al. (Eds.), Advances in Organic Geochemistry, 1981. J. Wiley and Sons, New York, pp. 684-697.

Bujak, J.P., Brinkhuis, H., 1998. Global warming and dinocyst changes across the Paleocene/Eocene boundary. In: Aubry, M.-P., Lucas, S.G., Berggren, W.A. (Eds.), Late Paleocene - Early Eocene Climatic and Biotic Events in the Marine and Terrestrial Records. Columbia University Press, New York, pp. 277-295.

Carvajal-Ortiz, H., Mora, G., Jaramillo, C., 2009. A molecular evaluation of bulk organic carbonisotope chemostratigraphy for terrestrial correlations: An example from two PaleoceneEocene tropical sequences. Palaeogeography, Palaeoclimatology, Palaeoecology 277, 173 183.

Cavagnetto, C., 2000. La palynoflore d'un gisement d'ambre de l'Eocène basal du Bassin Parisien (Le Quesnoy, France). Palaeontographica Abteilung B 255, 147-171.

Charles, A.J., Condon, D.J., Harding, I.C., Pälike, H., Marshall, J.E.A., Cui, Y., Kump, L., Croudace, I.W., 2011. Constraints on the numerical age of the Paleocene-Eocene boundary. Geochemistry Geophysics Geosystems 12. 
Chateauneuf, J.-J., Gruas Cavagnetto, C., 1968. Etude palynologique du Paléogène de quatre sondages du bassin parisien (Chaignes, Montjavoult, Le Tillet, Ludes). Mémoires du BRGM 59, 113 162.

Chikaraishi, Y., Naraoka, H., 2003. Compound-specific $\delta \mathrm{D}-\delta^{13} \mathrm{C}$ analyses of $n$-alkanes extracted from terrestrial and aquatic plants. Phytochemistry 63, 361-371.

Chikaraishi, Y., Naraoka, H., 2007. $\delta^{13} \mathrm{C}$ and $\delta \mathrm{D}$ relationships among three $n$-alkyl compound classes ( $n$-alkanoic acid, $n$-alkane and $n$-alkanol) of terrestrial higher plants. Organic Geochemistry $38,198-215$.

Collinson, M.E., Hooker, J.J., Griicke, D.R., 2003. Cobham lignite bed and penecontemporaneous macrofloras of southem England: A record of vegetation and fire across the Paleocene-Eocene Thermnal Maximum. In: Wing, S.L., Gingerich, P.D., Schmitz, B., Thomas, E. (Eds), Causes and Consequences of Globally Warm Climates in the Early Paleogene. Geological Society of America Special Papers 369, pp. 333-350.

Collinson, M.E., Steart, D.C., Harrington, G.J., Hooker, J.J., Scott, A.C., Allen, L.O., Glasspool, I.J., Gibbons, S.J., 2009. Palynological evidence of vegetation dynamics in response to palaeoenvironmental change across the onset of the Paleocene-Eocene Thermal Maximum at Cobham, Southern England. Grana 48, 38-66.

Collinson, M.E., Steart, D.C., Scott, A.C., Glasspool, I.J., Hooker, J.J., 2007. Episodic fire, runoff and deposition at the Palaeocene-Eocene boundary. Journal of the Geological Society of London 164, 87-97.

Corbet, B., Albrecht, P., Ourisson, G., 1980. Photochemical or photomimetic fossil triterpenoids in sediments and petroleum. Journal of the American Chemical Society 102, 1171-1173.

Cranwell, P.A., 1984. Lipid geochemistry of sediments from Upton Broad, a small productive lake. Organic Geochemistry 7, 25-37.

Crepet, W.L., Daghlian, C.P., 1981. Lower Eocene and Paleocene Gentianaceae: Floral and Palynological Evidence. Science, New Series 214, 75-77.

Crouch, E.M., Dickens, G.R., Brinkhuis, H., Aubry, M.-P., Hollis, C.J., Rogers, K.M., Visscher, H., 2003. The Apectodinium acme and terrestrial discharge during the Paleocene-Eocene thermal maximum: new palynological, geochemical and calcareous nannoplankton observations at Tawanui, New Zealand. Palaeogeography, Palaeoclimatology, Palaeoecology 194, 387-403.

Dickens, G.R., Oneil, J.R., Rea, D.K., Owen, R.M., 1995. Dissociation of oceanic methane hydrate as a cause of the carbon-isotope excursion at the end of the Paleocene. Paleoceanography 10 , 965-971.

Djerassi, C., Budzikiewicz, H., Wilson, J.M., 1962. Mass spectrometry in structural and stereochemical problems. Unsaturated pentacyclic triterpenoids. Tetrahedron Letters 3, 263 270.

Dupuis, C., Steurbaut, E., 1987. Altérites, sables marins (NP8, NP9) et fluviatiles, silicification et stromatolites dans le Paléocène supérieur entre Criel et le Cap d'Ailly (Haute-Normandie). Annales de la Société Géologique du Nord 105, 233-242. 
Dupuis, C., Gruas-Cavagnetto, C., 1985. Les Woolwich Beds et le London Clay de Newhaven (East Sussex), données stratigraphiques et palynologiques nouvelles. Bulletin d'information de l'Association des Géologues du Bassin de Paris 22, 19-33.

Dupuis, C., Steurbaut, E., De Coninck, J., Riveline, J., 1998. The Western Argiles à Lignites facies. In: Thiry, M., Dupuis, C. (Eds), The Paleocene/Eocene Boundary in the Paris Basin: The Sparnacian Deposits. Field Trip Guide. Ecole Nationale Supérieure des Mines de Paris, Mémoire des Sciences de la Terre 34, Paris, pp. 60-71.

Eglinton, G., Gonzalez, A.G., Hamilton, R.J., Raphael, R.A., 1962. Hydrocarbon constituents of the wax coatings of plant leaves: A taxonomic survey. Phytochemistry 1, 89-102.

Eglinton, G., Hamilton, R.J., 1967. Leaf Epicuticular Waxes. Science 156, 1322-1335.

Erdtman, G., 1960. The acetolysis method, a revised description. Svensk Botanisk Tidskrift 54, 561564.

Faegri, K., Iversen, J., 1989. Textbook of pollen analysis. J. Wiley and Sons, New York.

Feakins, S.J., Sessions, A.L., 2010. Controls on the D/H ratios of plant leaf waxes in an arid ecosystem. Geochimica et Cosmochimica Acta 74, 2128-2141.

Ficken, K.J., Wooller, M.J., Swain, D.L., Street-Perrott, F.A., Eglinton, G., 2002. Reconstruction of a subalpine grass-dominated ecosystem, Lake Rutundu, Mount Kenya: a novel multi-proxy approach. Palaeogeography, Palaeoclimatology, Palaeoecology 177, 137-149.

Fritel, P. H., 1910. Etude sur les végétaux fossiles de l'étage Sparnacien du bassin de Paris. Mémoire de la Société Géologique de France 40, 40 pp.

Garel, S., Schnyder, J., Jacob, J., Dupuis, C., Boussafir, M., Le Milbeau, C., Storme, J.-Y., Iakovleva, A.I., Yans, J., Baudin, F., Fléhoc, C., Quesnel, F., 2013. Paleohydrological and paleoenvironmental changes recorded in terrestrial sediments of the Paleocene-Eocene boundary (Normandy, France). Palaeogeography, Palaeoclimatology, Palaeoecology 376, 184-199.

Gingerich, P.D., 1989. New earliest Wasatchian mammalian fauna from the Eocene of northwestern Wyoming: composition and diversity in a rarely sampled high-floodplain assemblage. University of Michigan Papers on Paleontology 28, 1-97.

Gingerich, P.D., 2006. Environment and evolution through the Paleocene-Eocene thermal maximum. Trends in Ecology and Evolution 21, 246-253.

Gruas-Cavagnetto, C., 1966. Complexes sporo-polliniques du Sparnacien du Phare d'Ailly (Ouest de Dieppe, Seine-Maritime). Revue de Micropaléontologie 9, 57-67.

Gruas-Cavagnetto, C., 1968. Étude palynologique de divers gisements du Sparnacien du bassin de Paris. Mémoire de la Société Géologique de France 110, 1-144.

Gruas-Cavagnetto, C., 1978. Étude palynologique de l'Eocène du Bassin anglo-parisien. Mémoire de la Société Géologique de France 131, 1-60. 
Hagemann, H.W., Hollerbach, A., 1980. Relationship between the macropetrographic and organic geochemical composition of lignites. Physics and Chemistry of the Earth 12, 631-638.

Handley, L., Crouch, E.M., Pancost, R.D., 2011. A New Zealand record of sea level rise and environmental change during the Paleocene-Eocene Thermal Maximum. Palaeogeography, Palaeoclimatology, Palaeoecology 305, 185-200.

Handley, L., O’Halloran, A., Pearson, P.N., Hawkins, E., Nicholas, C.J., Schouten, S., McMillan, I.K., Pancost, R.D., 2012. Changes in the hydrological cycle in tropical East Africa during the Paleocene-Eocene Thermal Maximum. Palaeogeography, Palaeoclimatology, Palaeoecology $329-330,10-21$.

Handley, L., Pearson, P.N., McMillan, I.K., Pancost, R.D., 2008. Large terrestrial and marine carbon and hydrogen isotope excursions in a new Paleocene/Eocene boundary section from Tanzania. Earth and Planetary Science Letters 275, 17-25.

Harrington, G.J., Kemp, S.J., 2001. US Gulf Coast vegetation dynamics during the latest Palaeocene. Palaeogeography, Palaeoclimatology, Palaeoecology 167, 1-21.

Harrington, G.J., Clechenko, E.R., Clay Kelly, D., 2005. Palynology and organic-carbon isotope ratios across a terrestrial Palaeocene/Eocene boundary section in the Williston Basin, North Dakota, USA. Palaeogeography, Palaeoclimatology, Palaeoecology 226, 214-232.

Harrington, G.J., Jaramillo, C.A., 2007. Paratropical floral extinction in the Late Palaeocene-Early Eocene. Journal of the Geological Society 164, 323-332.

Hauke, V., Graff, R., Wehrung, P., Trendel, J.M., Albrecht, P., Riva, A., Hopfgartner, G., Gülaçar, F.O., Buchs, A., Eakin, P.A., 1992. Novel triterpene-derived hydrocarbons of the arborane/fernane series in sediments: Part II. Geochimica et Cosmochimica 56, 3595-3602.

Henderson, W., Wollrab, V., Eglinton, G., 1969. Identification of steranes and triterpanes from a geological source by capillary gas liquid chromatography and mass spectrometry. In: Schenck, P.A., Havenaar, I. (Eds.), Advances in Organic Geochemistry 1968. Pergamon, Oxford, pp. 181-207.

Higgins, J.A., Schrag, D.P., 2006. Beyond methane: Towards a theory for the Paleocene-Eocene Thermal Maximum. Earth and Planetary Science Letters 245, 523-537.

Jacob, J., Disnar, J.-R., Boussafir, M., Ledru, M.-P., Spadano Albuquerque, A.L., Sifeddine, A., Turcq, B., 2004. Onocerane attests to dry climatic events during the Quaternary in the tropics. Organic Geochemistry 35, 289-297.

Jacob, J., Disnar, J.-R., Boussafir, M., Spadano Albuquerque, A.L., Sifeddine, A., Turcq, B., 2005. Pentacyclic triterpene methyl ethers in recent lacustrine sediments (Lagoa do Caço, Brazil). Organic Geochemistry 36, 449-461.

Jacob, J., Disnar, J.-R., Boussafir, M., Spadano Albuquerque, A.L., Sifeddine, A., Turcq, B., 2007. Contrasted distributions of triterpene derivatives in the sediments of Lake Caço reflect paleoenvironmental changes during the last 20,000 yrs in NE Brazil. Organic Geochemistry 38, 180-197. 
Jansen, B., de Boer, E.J., Cleef, A.M., Hooghiemstra, H., Moscol-Olivera, M., Tonneijck, F.H., Verstraten, J.M., 2013. Reconstruction of late Holocene forest dynamics in northern Ecuador from biomarkers and pollen in soil cores. Palaeogeography, Palaeoclimatology, Palaeoecology $386,607-619$.

Jaramillo, C., Ochoa, D., Contreras, L., Pagani, M., Carvajal-Ortiz, H., Pratt, L.M., Krishnan, S., Cardona, A., Romero, M., Quiroz, L., Rodriguez, G., Rueda, M.J., De La Parra, F., Morón, S., Green, W., Bayona, G., Montes, C., Quintero, O., Ramirez, R., Mora, G., Schouten, S., Bermudez, H., Navarrete, R., Parra, F., Alvarán, M., Osorno, J., Crowley, J.L., Valencia, V., Vervoort, J., 2010. Effects of Rapid Global Warming at the Paleocene-Eocene Boundary on Neotropical Vegetation. Science 330, 957-961.

Kaiho, K., Arinobu, T., Ishiwatari, R., Morgans, H.E.G., Okada, H., Takeda, N., Tazaki, K., Zhou, G., Kajiwara, Y., Matsumoto, R., Hirai, A., Niitsuma, N., Wada, H., 1996. Latest Paleocene benthic foraminiferal extinction and environmental changes at Tawanui, New Zealand. Paleoceanography 11, 447-465.

Kannenberg, E.L., Poralla, K., 1999. Hopanoid Biosynthesis and Function in Bacteria. Naturwissenschaften 86, 168-176.

Kender, S., Stephenson, M.H., Riding, J.B., Leng, M.J., Knox, R.W.O., Peck, V.L., Kendrick, C.P., Ellis, M.A., Vane, C.H., Jamieson, R., 2012. Marine and terrestrial environmental changes in NW Europe preceding carbon release at the Paleocene-Eocene transition. Earth and Planetary Science Letters 353-354, 108-120.

Kennett, J.P., Stott, L.D., 1991. Abrupt deep-sea warming, palaeoceanographic changes and benthic extinctions at the end of the Paleocene. Nature 353, 225-229.

Killops, S. D., Killops, V.J., 2005. An Introduction to Organic Geochemistry, second ed. WileyBlackwell, Oxford.

Kimble, B., 1972. The geochemistry of triterpenoid hydrocarbons. Ph. D. thesis, University of Bristol.

Koch, P.L., Zachos, J.C., Gingerich, P.D., 1992. Correlation between isotope records in marine and continental carbon reservoirs near the Palaeocene/Eocene boundary. Nature 358, 319-322.

Krutzsch, W., 1957. Sporen- und Pollengruppen aus der Oberkreide und dem Tertiär Mitteleuropas und ihre stratigraphische Verteilung. Zeitschrift Für Angewandte Geologie 3, 509-548.

Krutzsch, W., Vanhoorne, R., 1977. Die Pollenflora von Epinois und Loksbergen in Belgien. Palaeontographica Abteilung B 163, 1-110.

Lavrieux, M., Jacob, J., Le Milbeau, C., Zocatelli, R., Masuda, K., Bréheret, J.-G., Disnar, J.-R., 2011. Occurrence of triterpenyl acetates in soil and their potential as chemotaxonomical markers of Asteraceae. Organic Geochemistry 42, 1315-1323.

Le Milbeau, C., Lavrieux, M., Jacob, J., Bréheret J.-G., Zocatelli, R., Disnar, J.-R., 2013. Methoxyserratenes in a soil under conifers and their potential use as biomarkers of Pinaceae. Organic Geochemistry 55, 45-54.

Logan, G.A., Eglinton, G., 1994. Biogeochemistry of the Miocene lacustrine deposit, at Clarkia, northern Idaho, U.S.A. Organic Geochemistry 21, 857-870. 
Loureiro, M.R.B., Cardoso, J.N., 1990. Aromatic hydrocarbons in the Paraiba Valley oil shale. Organic Geochemistry 15, 351-359.

Magioncalda, R., Dupuis, C., Blamart, D., Fairon-Demaret, M., Perreau, M., Renard, M., Riveline, J., Roche, M., Keppens, E., 2001. L'excursion isotopique du carbone organique $\left(\delta^{13} \mathrm{C}_{\mathrm{org}}\right)$ dans les paléoenvironnements continentaux de l'intervalle Paleocene/Eocene de Varangeville (HauteNormandie). Bulletin de la Société Géologique de France 172, 349-358.

Magioncalda, R., Dupuis, C., Smith, T., Steurbaut, E., Gingerich, P.D., 2004. Paleocene-Eocene carbon isotope excursion in organic carbon and pedogenic carbonate: Direct comparison in a continental stratigraphic section. Geology 32, 553-556.

Murphy, B.H., Farley, K.A., Zachos, J.C., 2010. An extraterrestrial ${ }^{3}$ He-based timescale for the Paleocene-Eocene thermal maximum (PETM) from Walvis Ridge, IODP Site 1266. Geochimica et Cosmochimica Acta 74, 5098-5108.

Noble, R., Alexander, R., Kagi, R., Knox, J., 1985. Tetracyclic diterpenoid hydrocarbons in some Australian coals, sediments and crude oils. Geochimica et Cosmochimica Acta 49, 21412147.

Ohmoto, T., Ikuse, M., Natori, S., 1970. Triterpenoids of the gramineae. Phytochemistry 9, 21372148.

Otto, A., Walther, H., Püttmann, W., 1997. Sesqui- and diterpenoid biomarkers preserved in Taxodium-rich Oligocene oxbow lake clays, Weisselster basin, Germany. Organic Geochemistry 26, 105-115.

Otto, A., Wilde, V., 2001. Sesqui-, di-, and triterpenoids as chemosystematic markers in extant conifers-A review. The Botanical Review 67, 141-238.

Ourisson, G., Albrecht, P., Rohmer, M., 1979. The Hopanoids: palaeochemistry and biochemistry of a group of natural products. Pure and Applied Chemistry 51, 709-729.

Pagani, M., Pedentchouk, N., Huber, M., Sluijs, A., Schouten, S., Brinkhuis, H., Sinninghe Damsté, J.S., Dickens, G.R., Expedition 302 Scientists, 2006. Arctic hydrology during global warming at the Palaeocene/Eocene thermal maximum. Nature 442, 671-675.

Paull, R., Michaelsen, B.H., McKirdy, D.M., 1998. Fernenes and other triterpenoid hydrocarbons in Dicroidium-bearing Triassic mudstones and coals from South Australia. Organic Geochemistry 29, 1331-1343.

Pearson, M.J., Obaje, N.G., 1999. Onocerane and other triterpenoids in Late Cretaceous sediments from the Upper Benue Trough, Nigeria: tectonic and palaeoenvironmental implications. Organic Geochemistry 30, 583-592.

Peters, K., Walters, C., Moldowan, M., 2005. The biomarker Guide. Biomarkers and Isotopes in the Petroleum Exploration and Earth History, vol. 2, second ed. Cambridge University Press, Cambridge.

Pflug, H., 1952. Palynologie und Stratigraphie der eozänen Braunkohlen von Helmstedt. Paläontologische Zeitschrift 26, 112-136. 
Pflug, H., 1953. Zur Entstehung und Entwicklung des angiospermiden Pollens in der Erdgesichte. Palaeontographica B 95, 60-171.

Philp, R.P., 1985. Fossil Fuel Biomarkers - Applications and Spectra. Elsevier, New York.

Regnery, J., Püttmann, W., Koutsodendris, A., Mulch, A., Pross, J., 2013. Comparison of the paleoclimatic significance of higher land plant biomarker concentrations and pollen data: A case study of lake sediments from the Holsteinian interglacial. Organic Geochemistry 61, 7384.

Riegel, W., Wilde, V., Lenz, O. K., 2012. The Early Eocene of Schöningen (N-Germany) - an interim report, Austrian Journal of Earth Sciences 105/1, 88-109.

Roche, E., 1973. Marqueurs stratigraphiques (pollen et spores) du Paléocène et de l'Eocène inférieur de Belgique. Académie Royale de Belgique. Bulletin de la classe des Sciences 59, 959-969.

Roche, E., Dupuis, C., Stambouli-Essassi, S., Russo-Ermolli, E., De Putter, T., Nicaise, N., FaironDemaret, M., 2008. Phytostratigraphie et paléoenvironnements du Néogène de l'EntreSambre-et- Meuse et du Condroz (Belgique). Evolution paléoclimatique du subtropical humide au tempéré froid. Geo-Eco-Trop 32, 101-130.

Roche, E., Quesnel, F., Dupuis, C., 2009. Tentative high resolution palynostratigraphy of the Early Eocene in the southern North Sea Basin. Abstract. International congress on Climatic and Biotic Events of the Paleogene, Wellington, New Zealand, p.140.

Rohmer, M., Anding, C., Ourisson, G., 1980. Non-specific Biosynthesis of Hopane Triterpenes by a Cell-Free System from Acetobacter pasteurianum. European Journal of Biochemistry 112, 541-547.

Rommerskirchen, F., Eglinton, G., Dupont, L., Güntner, U., Wenzel, C., Rullkötter, J., 2003. A north to south transect of Holocene southeast Atlantic continental margin sediments: Relationship between aerosol transport and compound-specific $\delta^{13} \mathrm{C}$ land plant biomarker and pollen records. Geochemistry, Geophysics, Geosystems 4, 1101-1129.

Sachse, D., Radke, J., Gleixner, G., 2004. Hydrogen isotope ratios of recent lacustrine sedimentary nalkanes record modern climate variability. Geochimica et Cosmochimica Acta 68, 4877-4889.

Sauer, P.E., Eglinton, T.I., Hayes, J.M., Schimmelmann, A., Sessions, A.L., 2001. Compound-specific $\mathrm{D} / \mathrm{H}$ ratios of lipid biomarkers from sediments as a proxy for environmental and climatic conditions. Geochimica et Cosmochimica Acta 65, 213-222.

Schmitz, B., Pujalte, V., 2007. Abrupt increase in seasonal extreme precipitation at the PaleoceneEocene boundary. Geology 35, 215-218.

Schouten, S., Woltering, M., Rijpstra, W.I.C., Sluijs, A., Brinkhuis, H., Sinninghe Damsté, J.S., 2007. The Paleocene-Eocene carbon isotope excursion in higher plant organic matter: Differential fractionation of angiosperms and conifers in the Arctic. Earth and Planetary Science Letters $258,581-592$.

Schwark, L., Zink, K., Lechterbeck, J., 2002. Reconstruction of postglacial to early Holocene vegetation history in terrestrial Central Europe via cuticular lipid biomarkers and pollen records from lake sediments. Geology 30, 463-466. 
Secord, R., Gingerich, P.D., Lohmann, K.C., MacLeod, K.G., 2010. Continental warming preceding the Palaeocene-Eocene thermal maximum. Nature 467, 955-958.

Shiojima, K., Ageta, H., 1990. Fern Constituents: Two New Triterpenoid Hydrocarbons, Hop-16-ene and Isohop-22(29)-ene, Isolated from Davallia mariesii. Chemical and Pharmaceutical Bulletin 38, 347-349.

Shiojima, K., Arai, Y., Masuda, K., Takase, Y., Ageta, T., Ageta, H., 1992. Mass Spectra of Pentacyclic Triterpenoids. Chemical and Pharmaceutical Bulletin 40, 1683-1690.

Sinninghe Damsté, J.S., Rijpstra, W.I.C., Reichart, G., 2002. The influence of oxic degradation on the sedimentary biomarker record II. Evidence from Arabian Sea sediments. Geochimica et Cosmochimica Acta 66, 2737-2754.

Sluijs, A., Schouten, S., Pagani, M., Woltering, M., Brinkhuis, H., Sinninghe Damsté, J.S., Dickens, G.R., Huber, M., Reichart, G.-J., Stein, R., Matthiessen, J., Lourens, L.J., Pedentchouk, N., Backman, J., Moran, K., Expedition 302 Scientists, 2006. Subtropical Arctic Ocean temperatures during the Palaeocene/Eocene thermal maximum. Nature 441, 610-613.

Smith, F.A., Freeman, K.H., 2006. Influence of physiology and climate on $\delta D$ of leaf wax $n$-alkanes from $\mathrm{C}_{3}$ and $\mathrm{C}_{4}$ grasses. Geochimica et Cosmochimica Acta 70, 1172-1187.

Smith, F.A., Wing, S.L., Freeman, K.H., 2007. Magnitude of the carbon isotope excursion at the Paleocene-Eocene thermal maximum: The role of plant community change. Earth and Planetary Science Letters 262, 50-65.

Smith, T., Rose, K.D., Gingerich, P.D., 2006. Rapid Asia-Europe-North America geographic dispersal of earliest Eocene primate Teilhardina during the Paleocene-Eocene thermal maximum. Proceedings of the Natural Academy of Sciences 103, 11223-11227.

Smith, T., Dupuis, C., Folie, A., Quesnel, F., Storme, J.-Y., Iacumin, P., Riveline, J., Missiaen, P., Ladevèze, S., Yans, J., 2011. A new terrestrial vertebrate site just after the Paleocene-Eocene boundary in the Mortemer Formation of Upper Normandy, France. Comptes Rendus Palevol $10,11-20$.

Snowdon, L.R., 1978. Organic geochemistry of the Upper Cretaceous/Tertiary delta complexes of the Beaufort-Mackenzie Basin. Ph. D. Thesis, Rice University.

Stefanova, M., Markova, K., Marinov, S., Simoneit, B.R.T., 2005. Biomarkers in the fossils from the Miocene-aged Chukurovo lignite, Bulgaria: sesqui- and diterpenoids. Bulletin of Geosciences 80, 93-97.

Steurbaut, E., Magioncalda, R., Dupuis, C., van Simaeys, S., Roche, E., Roche, M., 2003. Palynology, paleoenvironments, and organic carbon isotope evolution in lagoonal Paleocene-Eocene boundary settings in North Belgium. In: Wing, S.L., Gingerich, P.D., Schmitz, B., Thomas, E. (Eds.), Causes and Consequences of Globally Warm Climates in the Early Paleogene. Geological Society of America Special Papers 369, pp. 291-317.

Stockey, R. A., Manchester,S. R., 1988. A fossil flower with in situ Pistillipollenites from the Eocene of British Columbia. Canadian Journal of Botany 66, 313-318. 
Storme, J.-Y., Devleeschouwer, X., Schnyder, J., Cambier, G., Baceta, J.I., Pujalte, V., Di Matteo, A., Iacumin, P., Yans, J., 2012a. The Palaeocene/Eocene boundary section at Zumaia (BasqueCantabric Basin) revisited: new insights from high-resolution magnetic susceptibility and carbon isotope chemostratigraphy on organic matter $\left(\delta^{13} \mathrm{C}_{\text {org }}\right)$. Terra Nova $24,310-317$.

Storme, J.-Y., Dupuis, C., Schnyder, J., Quesnel, F., Garel, S., Iakovleva, A.I., Iacumin, P., Di Matteo, A., Sebilo, M., Yans, J., 2012b. Cycles of humid-dry climate conditions around the P/E boundary: new stable isotope data from terrestrial organic matter in Vasterival section (NW France). Terra Nova 24, 114-122.

Streibl, M., Herout, V., 1969. Terpenoids. Especially oxygenated mono-, sesqui- di- and triterpenes. In: Eglinton, G., Murphy, M.T.J. (Eds.): Organic Geochemistry. Methods and Results. Springer Verlag, Berlin, pp. 401-424.

Thiry, M., Dupuis, C., 1998. The Paleocene/Eocene Boundary in the Paris Basin: The Sparnacian Deposits. Field Trip Guide. Ecole Nationale Supérieure des Mines de Paris, Mémoire des Sciences de la Terre 34, Paris.

Tipple, B.J., Pagani, M., Krishnan, S., Dirghangi, S.S., Galeotti, S., Agnini, C., Giusberti, L., Rio, D., 2011. Coupled high-resolution marine and terrestrial records of carbon and hydrologic cycles variations during the Paleocene-Eocene Thermal Maximum (PETM). Earth and Planetary Science Letters 311, 82-92.

Traverse, A., 1988. Paleopalynology. Unwin Hyman, Boston.

Volkman, J.K., Allen, D.I., Stevenson, P.L., Burton, H.R., 1986. Bacterial and algal hydrocarbons in sediments from a saline Antarctic lake, Ace Lake. In: Leythaeuser, D., Rullkötter, J. (Eds.), Advances in Organic Geochemistry 1985. Pergamon Press, Oxford, pp. 671-681.

Westerhold, T., Röhl, U., Raffi, I., Fornaciari, E., Monechi, S., Reale, V., Bowles, J., Evans, H.F., 2008. Astronomical calibration of the Paleocene time. Palaeogeography, Palaeoclimatology, Palaeoecology 257, 377-403.

Willumsen, P.S., Schultz, B. P., Sylvester, R., 2013. Rapid warming at the PETM and its influence on vegetation in Denmark. Strati 2013, $1^{\text {st }}$ International Congress on Stratigraphy, Lisboa, Cienças Da Terra, Volume Especial 7, 29.

Wing, S.L., Harrington, G.J., Bowen, G.J., Koch, P.L., 2003. Floral change during the Initial Eocene Thermal Maximum in the Powder River Basin, Wyoming. In: Wing, S.L., Gingerich, P.D., Schmitz, B., Thomas, E. (Eds.), Causes and Consequences of early Paleogene Warm Climates. Geological Society of America Special Papers 369, pp. 49-64.

Wing, S.L., Harrington, G.J., Smith, F.A., Bloch, J.I., Boyer, D.M., Freeman, K.H., 2005. Transient Floral Change and Rapid Global Warming at the Paleocene-Eocene Boundary. Science 310, 993-996.

Zachos, J., Pagani, M., Sloan, L., Thomas, E., Billups, K., 2001. Trends, rhythms, and aberrations in global climate 65 Ma to present. Science, 292, 686-693.

Zachos, J.C., Röhl, U., Schellenberg, S.A., Sluijs, A., Hodell, D.A., Kelly, D.C., Thomas, E., Nicolo, M., Raffi, I., Lourens, L.J., McCarren, H., Kroon, D., 2005. Rapid Acidification of the Ocean during the Paleocene-Eocene Thermal Maximum. Science 308, 1611-1615. 
Zachos, J.C., Wara, M.W., Bohaty, S., Delaney, M.L., Petrizzo, M.R., Brill, A., Bralower, T.J., Premoli-Silva, I., 2003. A Transient Rise in Tropical Sea Surface Temperature during the Paleocene-Eocene Thermal Maximum. Science, New Series 302, 1551-1554.

Zocatelli, R., Jacob, J., Turcq, B., Boussafir, M., Sifeddine, A., Bernardes, M.C., 2010. Biomarker evidence for recent turf cultivation in Northeast Brazil (Lagoa do Boqueirão, RN State). Organic Geochemistry 41, 427-430. 


\section{Figure captions}

Fig. 1. Location of the Cap d'Ailly area and Vasterival section (modified from Dupuis et al., 1998).

Fig. 2. Vasterival section, lithological log, sampling and $n$-alkane $\mathrm{C}_{27} \delta^{13} \mathrm{C}$ curve (Garel et al., 2013). CIE, Carbon Isotope Excursion.

Fig. 3. GC-MS total ion chromatogram of aliphatic lipid fraction of sample 98 illustrating distribution of $n$-alkanes, tricyclic diterpenoids (emphasized in the 21-23.5 min range), des-A-triterpenoids and triterpenoids, including hopanoids. Internal standard, $5 \alpha$-cholestane.

Fig. 4. Vasterival relative concentrations of (b) tricyclic diterpanes; (c) des-A-lupane and des-A-olean13(18)-ene; (d) des-A-fernene, de-A-olean-12-ene and des-A-urs-12-ene; (e) $\mathrm{C}_{30}$ fernene; (f) hop17(21)-ene; (g) onocerane I; (h) and neohop-13(18)-ene (this study) in comparison with $n$-alkane $\mathrm{C}_{27}$ $\delta^{13} \mathrm{C}$ curve (a; Garel et al., 2013). Circles represent concentration in samples with very low amount of biomarkers.

Fig. 5. Vasterival number of pollen and spore counted, number of observed taxa, and relative proportion (\%) of fern spores, gymnosperm pollen and angiosperm pollen (this study) vs. $n$-alkane $\mathrm{C}_{27}$ $\delta^{13} \mathrm{C}$ curve (Garel et al., 2013). Squares represent the samples where fewer than 100 pollen and spores were counted.

Fig. 6. Correlation between hopanes relative concentration and relative concentration of (a) $C_{30}$ fernene; (b) des-A-fernene; between $\mathrm{C}_{30}$ fernene relative concentration and relative concentration of (c) hop-17(21)-ene; (d) neohop-13(18)-ene; and (e) onocerane I. 
Fig. 7. Vasterival relative concentration of fern biomarkers (b) and spores (c), gymnosperm biomarkers (d) and pollen (e), angiosperm biomarkers (f) and pollen (g) (this study) vs. $n$-alkane $\mathrm{C}_{27}$ $\delta^{13} \mathrm{C}$ curve (a; Garel et al., 2013). Yellow ribbons represent the interval of vegetation changes discussed in this work. Circles, same as in Fig. 4. Squares, same as in Fig. 5. I1. Interval one; I2. Interval two.

Fig. 8. Vasterival (b) Biomarkers and (c) spores/pollen ferns/gymnosperms/angiosperms peaks in abundance (this study) vs. (a) $n$-alkane $\mathrm{C}_{27} \delta{ }^{13} \mathrm{C}$ curve, (d) $n$ - $\mathrm{C}_{27} \delta \mathrm{D}$ and (e) $n$ - $\mathrm{C}_{27}$ relative proportions (Garel et al., 2013).

\section{Table captions}

Table 1. Compounds found in Vasterival samples. Symbols correspond to those in Fig. 3. 


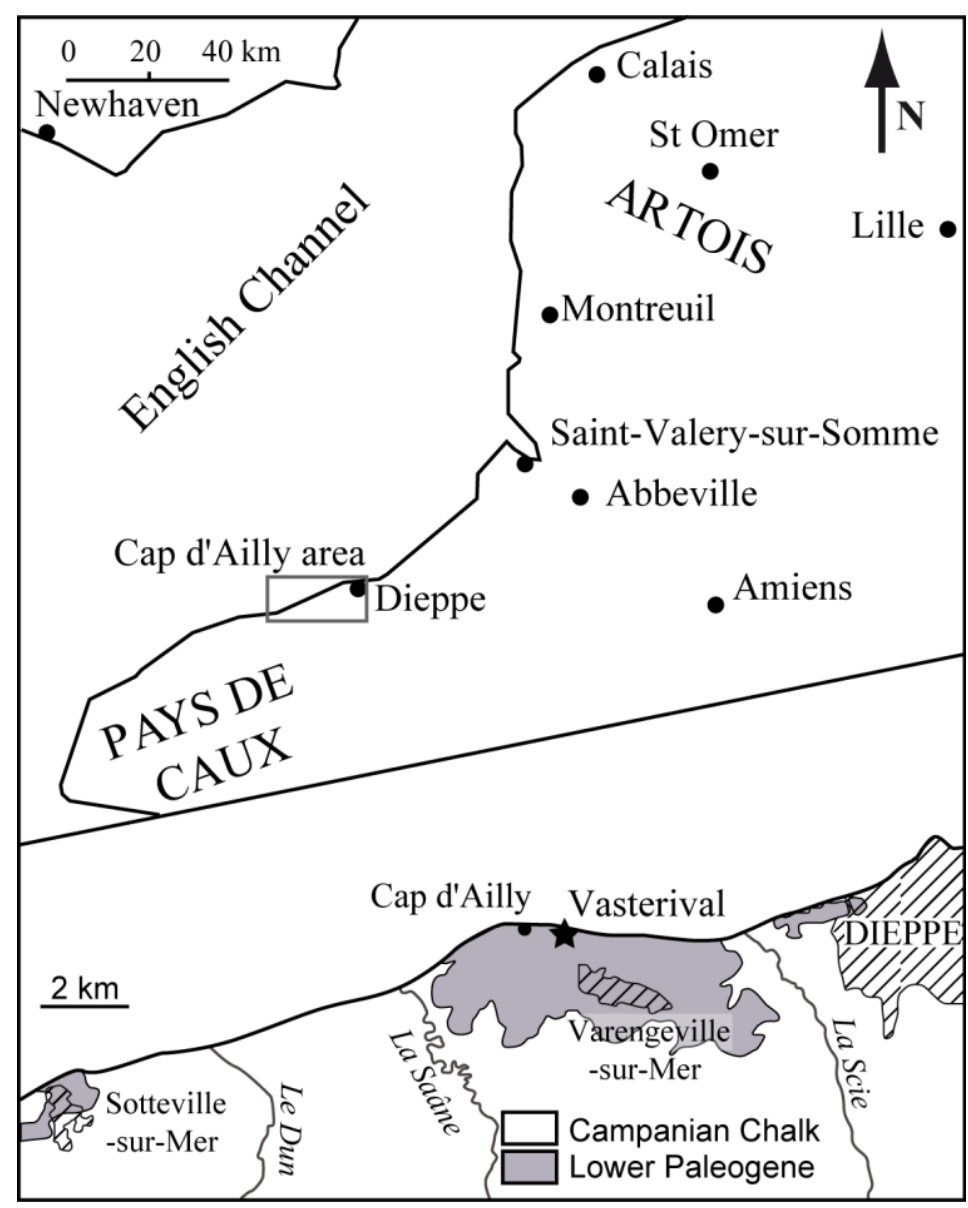

Figure 1 


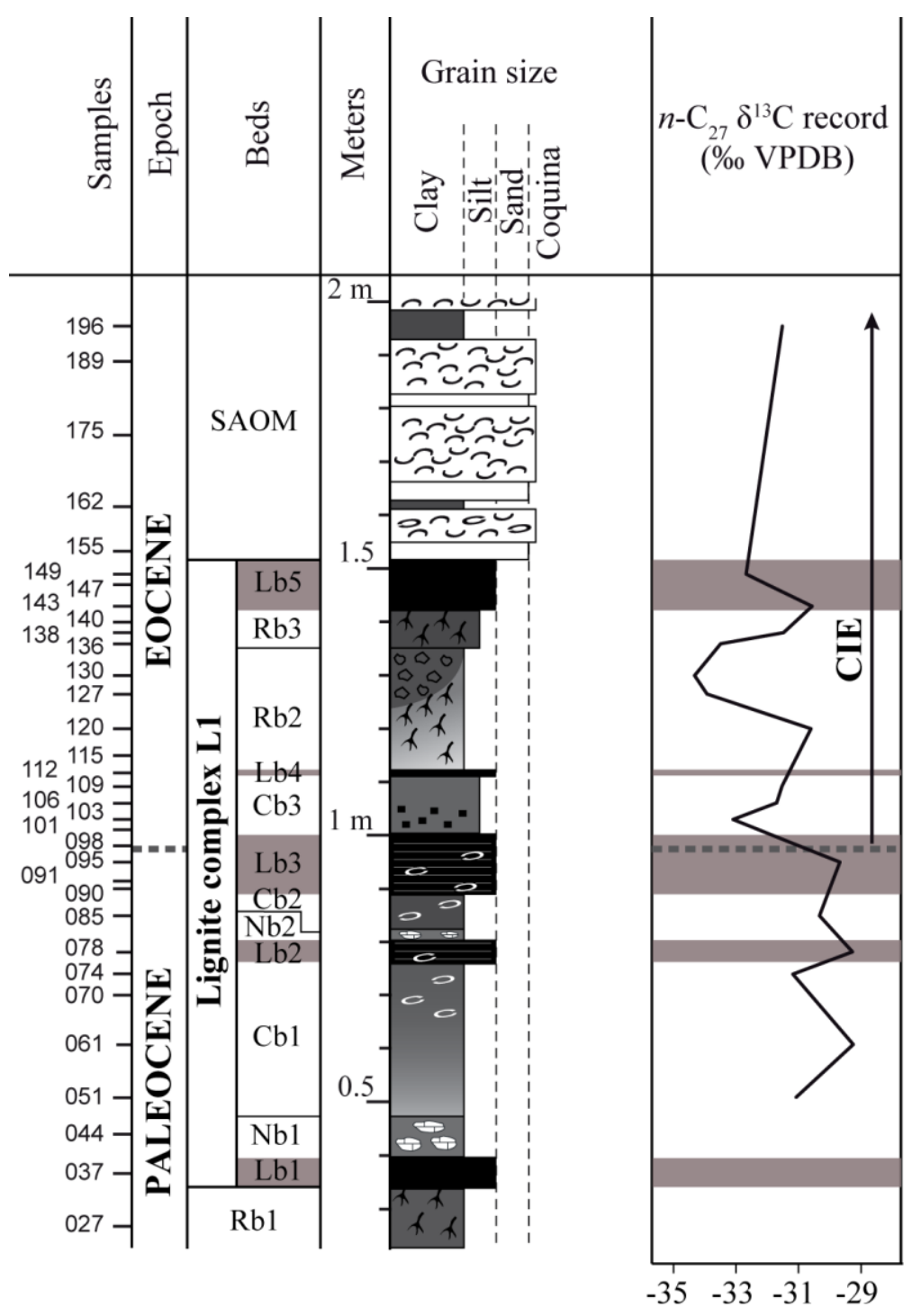

\section{LEGEND:}

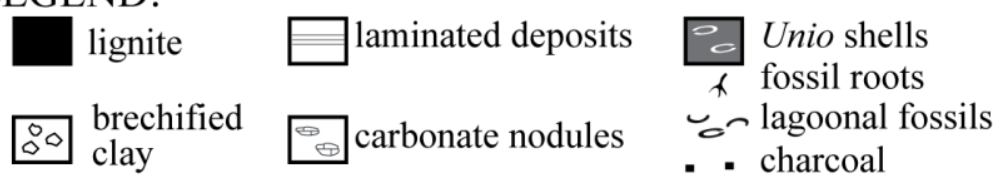

Figure 2 


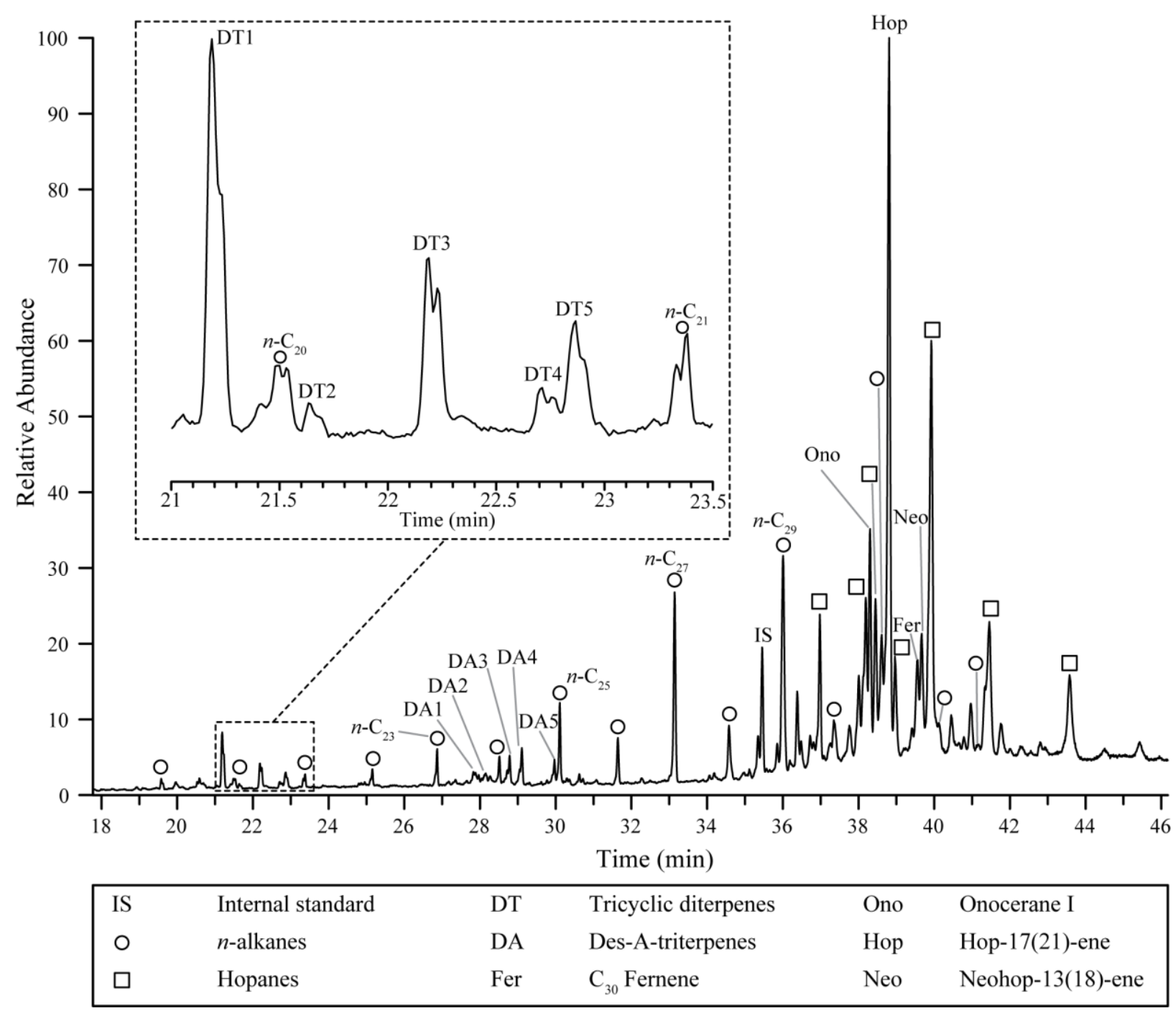

Figure 3 


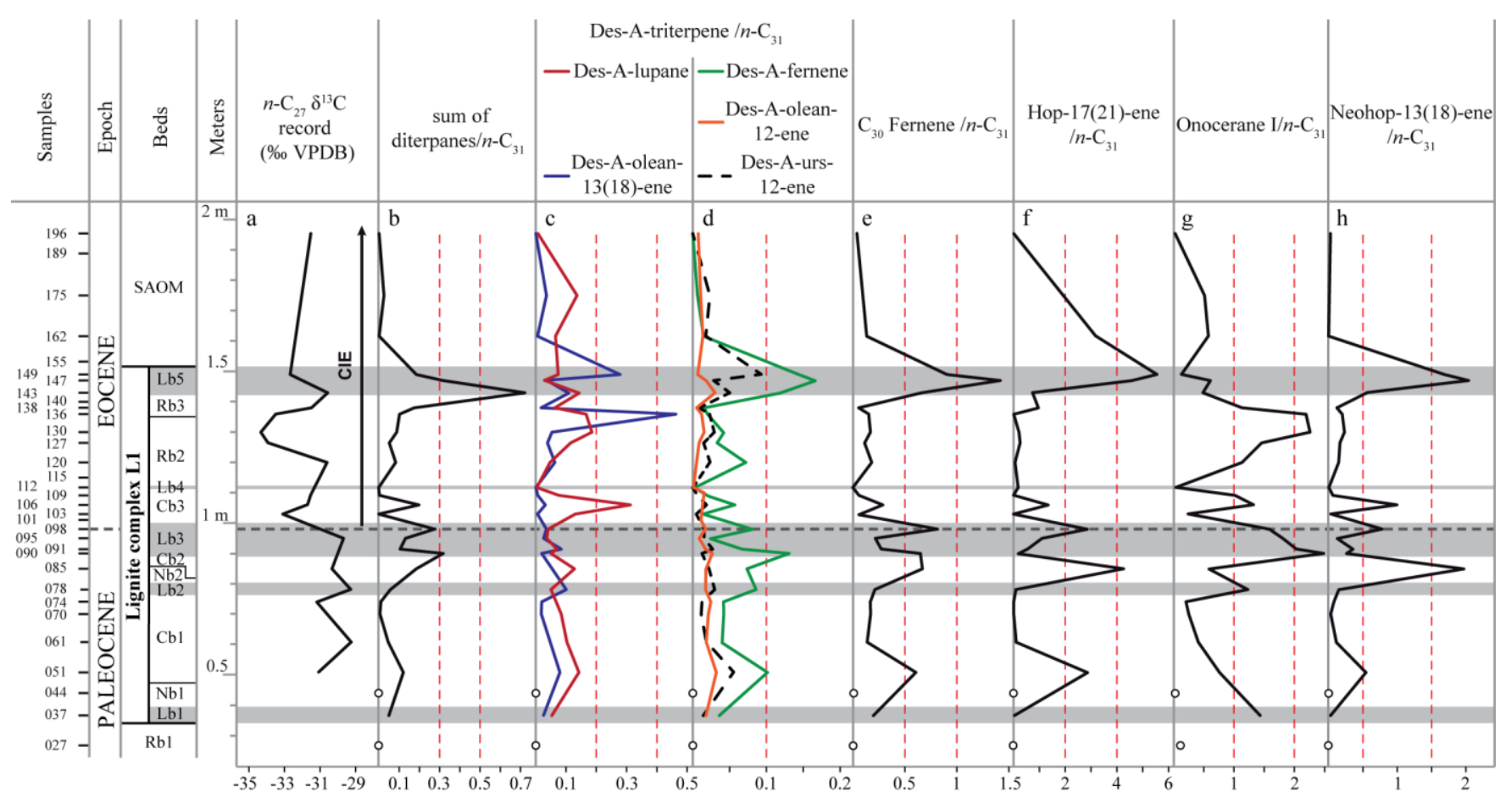

Figure 4 


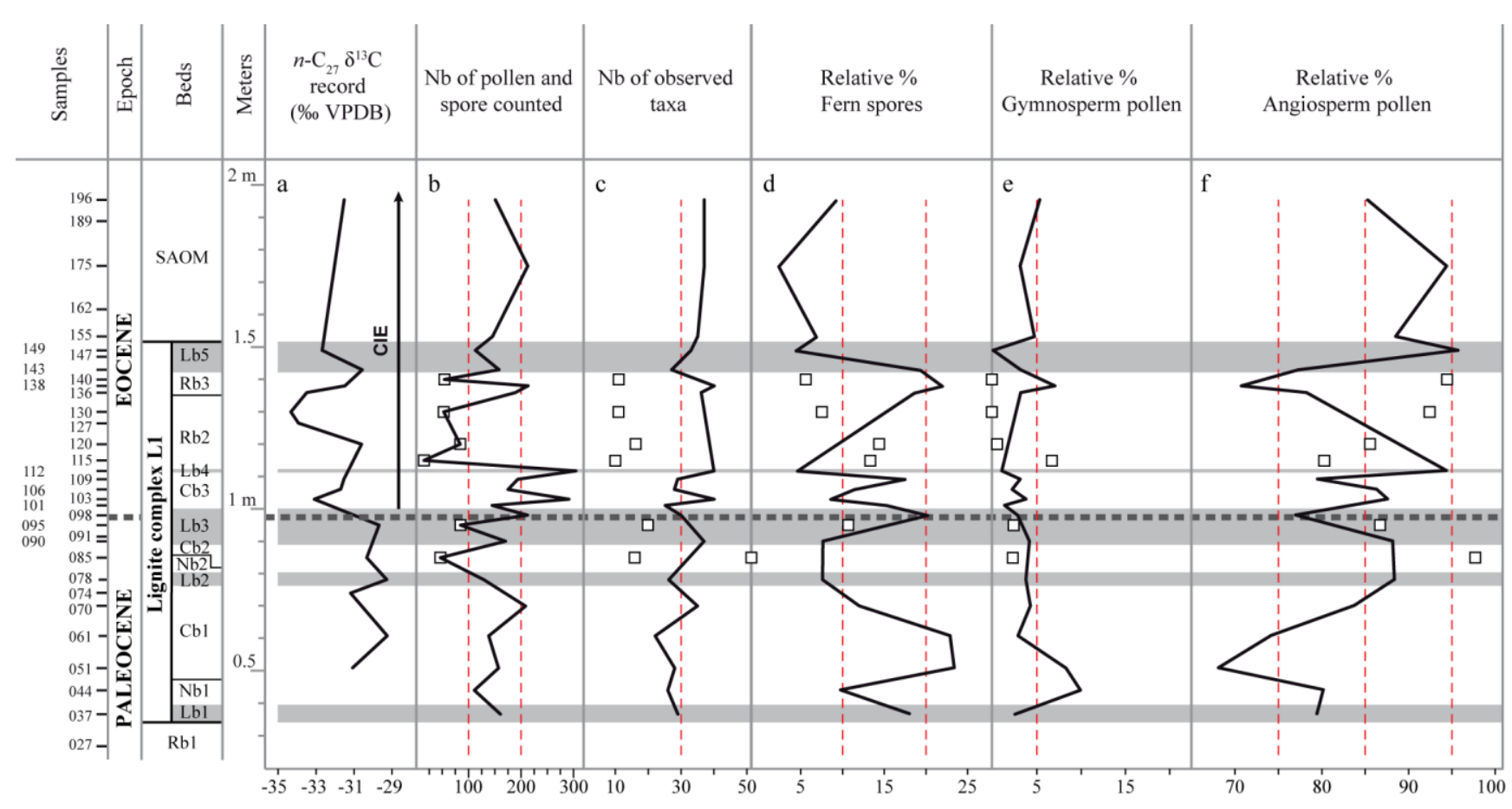

Figure 5 


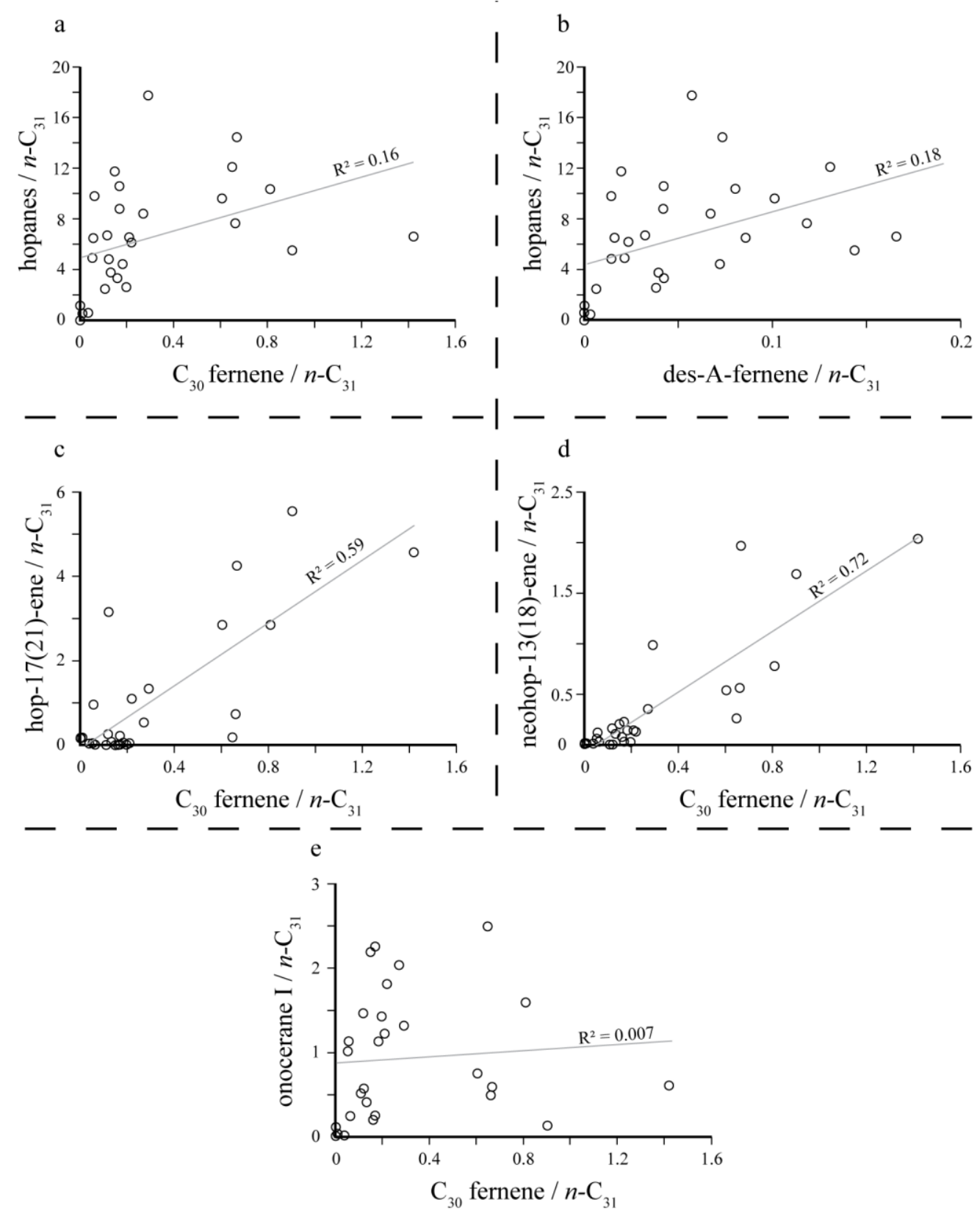

Figure 6 


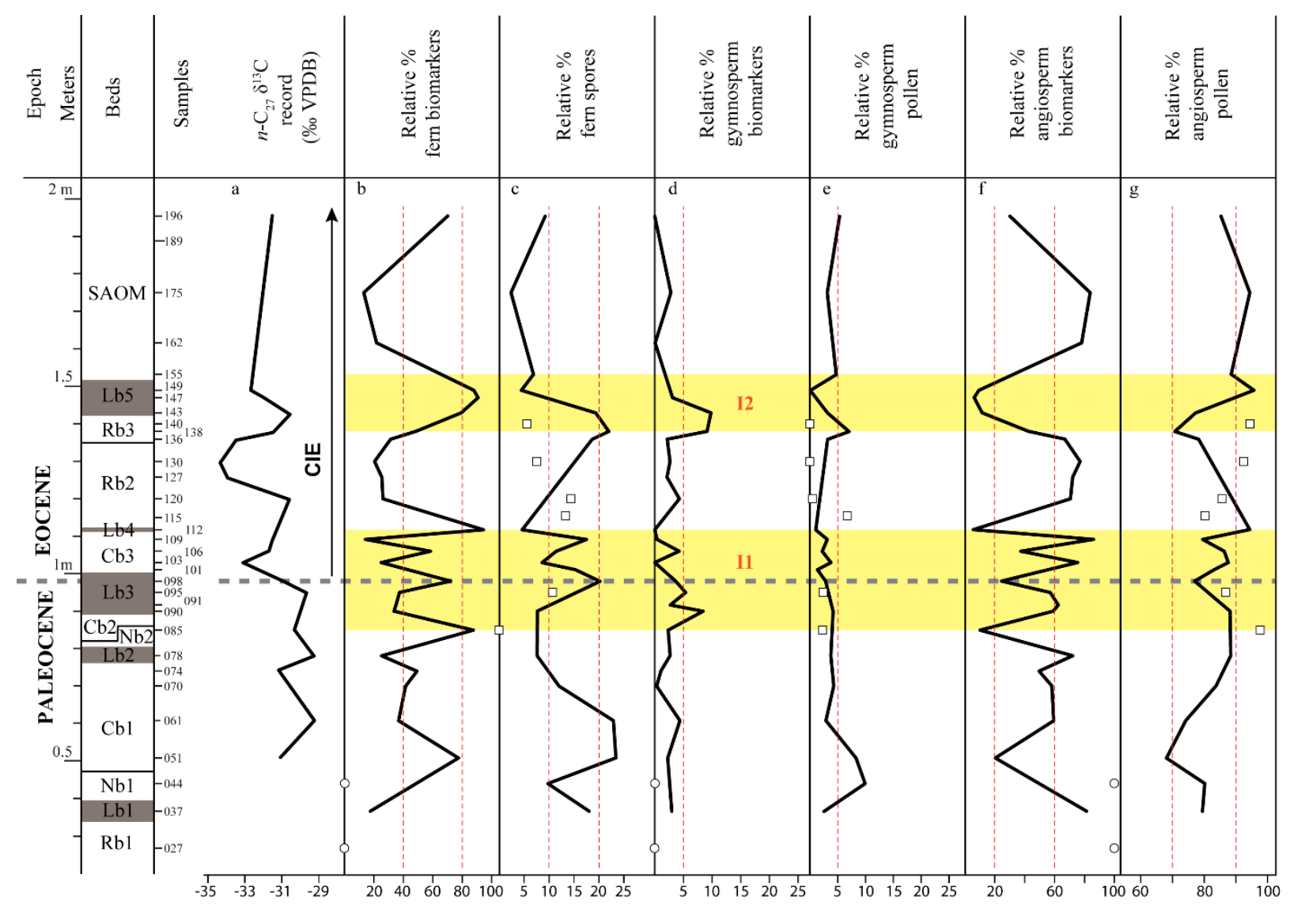

Figure 7 


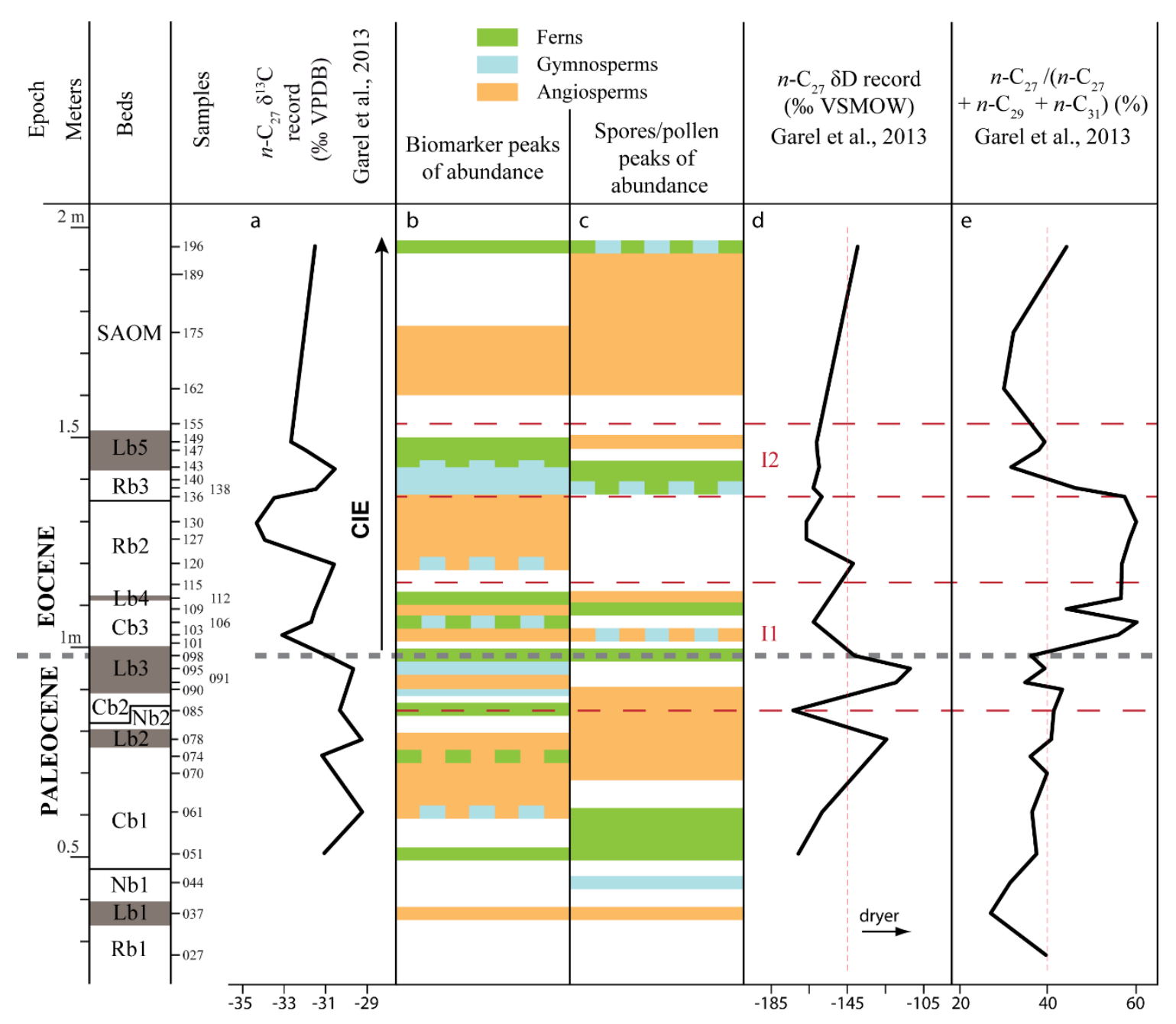

Figure 8 


\begin{tabular}{|c|c|c|c|c|c|}
\hline No. & $\begin{array}{c}\mathrm{Rt} \\
(\mathrm{min})\end{array}$ & $\begin{array}{l}\text { Group or Compound } \\
\text { name }\end{array}$ & $\mathrm{MW}$ & $\mathrm{m} / \mathrm{z}$ & References \\
\hline \multirow[t]{4}{*}{ IS } & 35.3 & $\begin{array}{l}5 \alpha \text { cholestane } \\
\text { (STANDARD) }\end{array}$ & 372 & 217 & \\
\hline & & $n$-alkanes & & & \\
\hline & $\begin{array}{c}11.6- \\
43\end{array}$ & C15-C34 & $\begin{array}{c}210- \\
476\end{array}$ & $55,71,85$ & \\
\hline & & Tricyclic Diterpenes & & & \\
\hline DT1 & 21.2 & Pimarane & 276 & $\begin{array}{l}163,191 \\
247\end{array}$ & Otto et al., 1997 \\
\hline DT2 & 21.6 & Sandaracopimarane? & 276 & $\begin{array}{l}163,191 \\
247\end{array}$ & Snowdon, 1978 \\
\hline DT3 & 22.2 & Diterpane C20 & 276 & $\begin{array}{l}191,163 \\
261\end{array}$ & Philp, 1985 \\
\hline DT4 & 22.7 & Diterpane C20 & 276 & $\begin{array}{l}191,163 \\
123\end{array}$ & Philp, 1985 \\
\hline \multirow[t]{2}{*}{ DT5 } & 22.8 & $\begin{array}{l}\text { Diterpene C20: } \\
\text { phyllocladene? }\end{array}$ & 274 & $\begin{array}{c}123,259 \\
231 \\
\end{array}$ & Philp, 1985 \\
\hline & & Des - A - Triterpenes & & & \\
\hline DA1 & 27.8 & Des-A-olean-13(18)-ene & 328 & $\begin{array}{c}189,204 \\
313\end{array}$ & $\begin{array}{c}\text { Logan and Eglinton, 1994; } \\
\text { Corbet, } 1980\end{array}$ \\
\hline DA2 & 28.2 & Des-A-olean-12-ene & 328 & $\begin{array}{c}203,218 \\
189 \\
\end{array}$ & $\begin{array}{c}\text { Logan and Eglinton, 1994; } \\
\text { Corbet, } 1980\end{array}$ \\
\hline DA3 & 28.8 & Des-A-urs-12-ene & 328 & $\begin{array}{c}218,313 \\
189 \\
\end{array}$ & $\begin{array}{c}\text { Logan and Eglinton, 1994; } \\
\text { Corbet, } 1980\end{array}$ \\
\hline DA4 & 29.1 & Des-A-lup-ane & 330 & $\begin{array}{c}163,149 \\
191 \\
\end{array}$ & Corbet, 1980; Philp, 1985 \\
\hline \multirow[t]{3}{*}{ DA5 } & 29.9 & Des-A-fernene & 328 & $\begin{array}{c}231,313 \\
243\end{array}$ & Loureiro and Cardoso, 1990 \\
\hline & \multicolumn{2}{|c|}{ Pentacyclic Triterpenes } & & & \\
\hline & & Fernenes & & & \\
\hline \multirow[t]{2}{*}{ Fer } & 39.5 & C30 Fernene & 410 & $\begin{array}{c}255,243 \\
257 \\
\end{array}$ & Paull et al., 1998 \\
\hline & & Hopanes & & & \\
\hline$\square$ & $\begin{array}{c}37.1- \\
43.7 \\
\end{array}$ & C27-C32 & $\begin{array}{c}356- \\
454\end{array}$ & 191 & \\
\hline Hop & 38.8 & Hop-17(21)-ene & 410 & $\begin{array}{c}161,367 \\
231\end{array}$ & Ageta et al., 1987 \\
\hline \multirow[t]{2}{*}{$\mathrm{Neo}$} & 39.6 & Neohop-13(18)-ene & 410 & $\begin{array}{l}191,218 \\
203\end{array}$ & Ageta et al., 1987 \\
\hline & & Others & & & \\
\hline Ono & 38.4 & Onocerane I & 414 & $\begin{array}{l}123,191 \\
399\end{array}$ & Pearson and Obaje, 1999 \\
\hline
\end{tabular}

Table 1 